NBER WORKING PAPER SERIES

VIOLENCE AGAINST WOMEN:

A CROSS-CULTURAL ANALYSIS FOR AFRICA

\author{
Alberto Alesina \\ Benedetta Brioschi \\ Eliana La Ferrara \\ Working Paper 21901 \\ http://www.nber.org/papers/w21901 \\ NATIONAL BUREAU OF ECONOMIC RESEARCH \\ 1050 Massachusetts Avenue \\ Cambridge, MA 02138 \\ January 2016
}

We thank James Fenske, Andreas Kotsadam, Ross MacMillan and Ana Tur-Prats for helpful comments. The views expressed herein are those of the authors and do not necessarily reflect the views of the National Bureau of Economic Research.

NBER working papers are circulated for discussion and comment purposes. They have not been peerreviewed or been subject to the review by the NBER Board of Directors that accompanies official NBER publications.

(C) 2016 by Alberto Alesina, Benedetta Brioschi, and Eliana La Ferrara. All rights reserved. Short sections of text, not to exceed two paragraphs, may be quoted without explicit permission provided that full credit, including $(\mathcal{C}$ notice, is given to the source. 
Violence Against Women: A Cross-cultural Analysis for Africa

Alberto Alesina, Benedetta Brioschi, and Eliana La Ferrara

NBER Working Paper No. 21901

January 2016

JEL No. E62

\begin{abstract}
$\underline{\text { ABSTRACT }}$
Using a new dataset, we investigate the determinants of violence against women in Africa. We focus on cultural factors arising from pre-colonial customs and find evidence consistent with two hypotheses. First, ancient socioeconomic conditions determine social norms about gender roles, family structures and intrafamily violence which persist even when the initial conditions change. Norms about marriage patterns, living arrangements and the productive role of women are associated with contemporary violence. Second, women's contemporary economic role affects violence in a complex way which is itself related to traditional norms in ancient times and current bargaining power within the marriage.
\end{abstract}

Alberto Alesina

Department of Economics

Harvard University

Littauer Center 210

Cambridge, MA 02138

and IGIER

and also NBER

aalesina@harvard.edu

Benedetta Brioschi

Bocconi University

Via Sarfatti, 25 Milano

benedetta.brioschi@unibocconi.it
Eliana La Ferrara

Universita' Bocconi

Dept. of Economics and IGIER

via Roentgen 1

20136 Milano

Italy

eliana.laferrara@unibocconi.it 


\title{
Violence Against Women: A Cross-cultural Analysis for Africa*
}

\author{
Alberto Alesina ${ }^{\dagger} \quad$ Benedetta Brioschi $^{\ddagger} \quad$ Eliana La Ferrara ${ }^{\S}$
}

This draft: January 2016

\begin{abstract}
Using a new dataset, we investigate the determinants of violence against women in Africa. We focus on cultural factors arising from pre-colonial customs and find evidence consistent with two hypotheses. First, ancient socioeconomic conditions determine social norms about gender roles, family structures and intrafamily violence which persist even when the initial conditions change. Norms about marriage patterns, living arrangements and the productive role of women are associated with contemporary violence. Second, women's contemporary economic role affects violence in a complex way which is itself related to traditional norms in ancient times and current bargaining power within the marriage.
\end{abstract}

\section{Introduction}

Violence perpetrated by men against their female partners is widespread around the world. It is a fundamental violation of women's human rights, and is also a significant public health problem, with significant economic and social costs. Victims of violence suffer physical and psychological distress, they may suffer isolation, experience a decline in labor productivity and

${ }^{*}$ We thank James Fenske, Andreas Kotsadam, Ross MacMillan and Ana TurPrats for helpful comments. All remaining errors are our own. Correspondence: aalesina@harvard.edu, benedetta.brioschi@unibocconi.it, eliana.laferrara@unibocconi.it

${ }^{\dagger}$ Harvard University and IGIER

${ }^{\ddagger}$ Bocconi University

${ }^{\S}$ Bocconi University and IGIER 
loss of wages, with consequences on children's health and education. ${ }^{1}$. The World Health Organization (2013) estimates that more than one third of women in the world have been victims of either physical or sexual violence, with low income countries disproportionately affected.

In this paper we assess how economic and cultural factors influence current spousal violence in Africa using data on domestic violence from the Demographic and Health Surveys (DHS). We combine these data with information on ancestral anthropological and cultural practices of the ethnic group to which the woman belongs, taken from Murdock's Ethnographic Atlas. The resulting new dataset allows us to uncover the role played by cultural origin in shaping contemporary attitudes towards and experience of domestic violence.

We find evidence for two interrelated hypotheses. The first is that the economic productivity of women affects men's violence against them. When in ancient times socioeconomic arrangements made women economically valuable, social norms developed in ways that viewed women as productive, more equal to men and these gender roles bring about less intrafamily violence. However, additional and subtle factors may come into play. An economically more independent woman may also have more bargaining power within the marriage, which may lead to a negative reaction of men and ultimately to an increase -as opposed to a decrease- in violence. Indeed, when exploring contemporaneous correlates of intimate partner violence, we find that if women currently work, spousal violence against them is higher.

The second (related) hypothesis is that past socioeconomic conditions determine persistent cultural values regarding the family, and violence against women. These values are persistent even when the initial conditions which generated them evolve or disappear. We find that in societies where women were actively involved in subsistence activities (e.g., those based upon gathering), women's role was more highly regarded and violence against women is lower today. On the contrary, violence is higher in societies based upon

\footnotetext{
${ }^{1}$ See the World Health Organization (2004). Carbone-López, Kruttschnitt and Macmillan (2006) estimate the contributions of different types of intimate partner violence exposure to physical health, mental health and substance abuse. Duvvury, Callan, Carney and Raghavendra (2013) provide a review of different costing methodologies and types of costs related to domestic violence that can be estimated depending on data availability. Women's Advocates Inc. (2002) calculates that intimate partner violence costs the US economy $\$ 12.6$ billion on an annual basis, that is, 0.12 percent of the GDP. This estimate includes legal and medical services, judicial system costs and lost productivity. Unfortunately, estimates of the costs associated with spousal violence are only available for developed countries, no similar studies were found for Sub-Saharan Africa.
} 
plough agriculture, where women participated less in agriculture (see Alesina, Giuliano and Nunn, 2013) and in fishing and hunting societies, which were mainly male activities, at least in our sample. Also ancestral living conditions of different ethnicities affect current levels of violence.

Female descendants of societies characterized by brideprice in the past are exposed to a lower probability and a lower intensity of violence today. This suggests that if men traditionally had to pay for marrying their wives, they attributed a greater value to them and they cared more about them. Interestingly, in line with this argument, lower actual violence is empirically associated with a lower acceptability of wife beating on the part of men.

Furthermore, being from an ethnicity that was traditionally endogamous (i.e., where members marry within the same ethnic group) has a positive and significant impact on spousal violence episodes. This may reflect less "modern" cultural values of ethnicities which practiced endogamy, or the possibility that beating a wife from a different ethnic group may bring about retaliation across ethnicities. We also find that where the stem family (a small extended family in which two generations cohabit, as one son stays at the parental homestead with his wife and children) was socially predominant in the past, both men and women tend to be less favorable to violence. This result confirms for Africa the hypothesis advanced and tested by Tur-Prats (2015) for Spain, namely that in stem families wives have more time to work on the farm, while the mother in law takes care of the children, hence they become more 'valuable'.

Finally, we explore the role of different types of settlements and find that women whose ancestors lived in nomadic and isolated settlements are exposed to a higher probability of violence and are more prone to justify it. Men whose ancestors lived in compact settlements are less likely to justify abuses against their wives. One interpretation is that nomadic and isolated settlements represent less developed communities; another is that societal protection of women is more difficult within these types of living arrangements.

Our paper makes two contributions to the existing literature. First, to the best of our knowledge, our work is the first one to combine data for all DHS surveys available for Africa in order to investigate contemporaneous as well as ancestral correlates of spousal violence and attitudes towards it. $^{2}$ Second, by assembling an original dataset that matches ethnic groups

\footnotetext{
${ }^{2}$ Heise and Kotsadsam (2015) and Cools and Kotsadam (2015) evaluate different correlates of domestic violence and attitudes towards this phenomenon, but they focus just
} 
in the DHS with information on ancestral characteristics from Murdock's Ethnographic Atlas, we are able to shed light on the origin and long term persistence of gender norms conducive to gender based violence. Our findings highlight the importance of considering deeply rooted social norms when discussing policies aimed at preventing or stopping domestic violence in low income countries.

The remainder of our paper is organized as follows. Section 2 introduces a brief review of the literature related to this subject. Section 3 describes the data and our matching procedures. Section 4 presents the empirical strategy and the results. Section 5 offers some robustness checks. The last section concludes.

\section{Related literature and hypotheses}

\subsection{The literature}

The present paper is related to the literature on the determinants of domestic violence and on the persistence of cultural values.

The literature on domestic violence cuts across disciplinary boundaries (see Lawson (2012) for a survey). One branch of sociological studies embraces a "feminist perspective" which analyzes violence against women as an expression of male dominance (e.g., Dobash and Dobash (1979) and Jonhson (1995)). Instead the 'ecological theory' underlines the importance of environmental factors and social relations and relates violence against women to various micro and macro variables inside and outside the family. ${ }^{3}$ The exchange and social control theory calls attention to the relative benefits and costs of domestic violence for the individual and emphasizes the role of social control against family violence which may increase the cost of violence for men (e.g., Gelles (1983) and Gelles and Strauss (1988)).

In recent years, a large literature has investigated the link between income gap and spousal violence. The pioneering study is Gelles (1976), who observes that the fewer resources a woman has, the more likely she is to be abused. Farmer and Tiefenthaler (1997) conclude that in the United States an improvement in women's economic opportunities leads to a decline in spousal violence. Bowlus and Seitz (2006) use structural methods to estimate a negative effect of female employment on abuse. Aizer (2010)

on contemporaneous correlates.

${ }^{3}$ See Heise (1998) for a discussion of how to reconcile the two perspectives. 
exploits administrative data to build a new measure of violence, based on female hospitalizations for assault, and she concludes that the decline in wage gap occurred in previous years reduces violence against women. ${ }^{4}$ Heise and Kotsadam (2015) use data from DHS and WHO and observe that partner's violence is less prevalent in countries with a high proportion of women in the work force, but working for cash increases a woman's risk in countries where women employment is lower. Cools and Kotsadam (2015), like Gelles (1976), conclude that resource inequality, both within the household and at the aggregate level, is associated with more spousal abuse in Africa.

Another view posits that spousal violence is a bargaining instrument, adopted by the husband to impose his control (Anderson, (1997); Gartner and Macmillan (1999); Johnson and Ferraro (2000)). This is the socalled male backlash theory, according to which husbands feel their authority threatened if their wives work, so they use violence as a way to reinstate their power. Bertrand, Kamenica and Pan (2015) find that in the United States couples where the wife earns more than the husband are less happy, are more likely to divorce and the wife spends more time on household chores. In societies that are more patriarchal and conservative and where divorce is not socially accepted, growing tensions within the couple generated by increasing economic opportunities for women may result in higher levels of intimate partner violence. Bloch and Rao (2002) find that in India, women whose family of origin is richer are more likely to be victims of domestic violence. Given that divorce is stigmatized, a woman can hardly escape from an abusive husband. Since violence is interpreted as a signal of husband's dissatisfaction, the only way for a woman's parents to stop the husband's abuses is to pay him. Economists and psychologists have recently investigated how a violent behavior can be a reaction to frustration. Card and Dahl (2011) show that an unexpected loss when the home football team is the favorite is associated with an increase in the rate of intimate partner violence.

Secondly, our work relates to the literature on the impact of historical legacies on current outcomes of violence. Pollak (2004) shows a high degree of intergenerational correlation of spousal violence. ${ }^{5}$ The importance

\footnotetext{
${ }^{4}$ The relationship between income gap and intimate partner violence has been analyzed also by criminologists. They developed a theory of exposure reduction according to which an increase in employment among either men or women will negatively affect domestic violence, by reducing the time partners spend together (Dugan, Nagin and Rosenfeld, 1999).

${ }^{5}$ This is consitent with the argument by Wolfang and Ferracuti (1967) on the intergen-
} 
of intergenerational transmission for shaping gender roles is also stressed by Thornton, Alwin and Camburn (1983) and Fernández, Fogli and Olivetti (2004). Tur-Prats (2015) focuses on Spain, and shows that territories where stem family was socially predominant in the past are characterized by a lower prevalence of domestic violence today. ${ }^{6}$ She explains this finding with a model in which co-residence with the mother-in-law increases the productive role of the wife, improving her participation in agricultural activities. The presence of an older woman in the household decreases the burden of domestic work for the wife, freeing up time for farming.

Probably the paper more directly related to ours, at least methodologically, is by Michalopoulos, Putterman and Weil (2014). They estimate the effect of ancestral lifeways on current economic outcomes, focusing on SubSaharan Africa and matching individual data from the Demographic and Health Surveys with ethnographic characteristics of distinct ethnic groups from Ethnographic Atlas. They observe that descendants of societies that were traditionally dependent on agriculture are wealthier and better educated. While they investigate the impact of descending from ethnicities that traditionally practiced agriculture on distinct current outcomes (men's education, wealth, etc.), we focus specifically on domestic violence and we try to uncover the role played by a broader set of cultural and societal factors.

The economic literature has also tried to provide an explanation about the distant origins of gender roles. Alesina, Giuliano and Nunn (2013) empirically test Ester Boserup's hypothesis that differences in gender roles are determined by historical agricultural practices. In particular, descendants of societies that practiced plough agriculture prior to industrialization are characterized by more unequal gender norms today. This is due to the fact that the use of plough required more physical strength, so in societies based on plough women started to be relegated into the domestic sphere. Conversely, in hoe culture, women were more likely to work outside the home and assume more important social roles, a feature that was then transmitted to their female descendants. They test these predictions and conclude that descendants of societies that practiced plough agriculture are characterized by a higher degree of gender inequality today. Studying the variation in poligamy across African societies, Fenske (2015) shows that districts that received more colonial teachers in French West Africa and areas that re-

erational trasmission of a culture of violence.

${ }^{6}$ A stem family is a family arrangement in which two generations cohabit, since one son stays at the parental homestead with his wife and kids. It is the opposite of nuclear family, where all children leave the parents' household to start their independent household. 
ceived more Christian missions have lower polygamy rates today.

\subsection{Our hypothesis}

The available literature suggests two main interrelated hypotheses which we will test on African data. The first is the role of the economic productivity of women as a determinant of domestic violence. To the extent that women are more valuable, in economic terms, violence should decline since the husband does not want to 'damage' physically and psychologically a productive member of the family. On the other hand, women who are more economically active also gain power in intrafamily bargaining. This may be difficult for the husband to accept, and even become unacceptable for some men in cases where the wife is more productive (e.g, receives a higher wage or more generally brings home more money or goods) than the husband. This second effect may lead to an increase in intrafamily violence.

The second hypothesis we test relates to the persistence over time of cultural values, and specifically of values regarding gender roles, family organization and gender based violence. Pre-colonial socioeconomic arrangements, often related to geographic conditions, led to certain family structures and gender roles, which in turn favoured or discouraged violence against women. We hypothesize that these cultural traits may have persisted even when the original socioeconomic conditions changed.

\section{Data}

\subsection{Demographic and Health Surveys}

We combine several data sources. Our main data source is constituted by the Demographic and Health Surveys (DHS), a series of representative crosssectional surveys of women and men aged 15-49 in randomly selected households. We use the most recently available DHS wave for those African countries for which either the domestic violence module or data on attitudes towards intimate partner violence are available. ${ }^{7}$ In order to match the DHS individual level data with Murdock's Ethnographic Atlas (see below) we need to restrict the analysis to only those DHS waves in which the ethnicity or language of the household members was collected. We use language

\footnotetext{
${ }^{7}$ We decided to consider only African countries because the number of non-African countries for which both the violence module and data on the ethnicity (or language) of the respondent are available is negligible.
} 
spoken at home or native language as a proxy for ethnicity when information on respondent's ethnic group is not available. We analyze intimate partner violence at three different levels: (i) actual episodes of violence experienced by women, and attitudes towards violence of (ii) women and (iii) men.

Actual violence experienced. We consider all the women selected and interviewed for the domestic violence module which is included in some DHS survey rounds for 18 countries. $^{8}$ Eliciting information on domestic violence is difficult for obvious reasons, but the DHS protocol has high standards to ensure high data quality. First, the domestic violence module is administered to only one (randomly selected) woman per household: this ensures that other respondents in the household will not know about the questions she was asked. Informed consent for the survey is obtained from the respondent at the beginning of the individual interview. At the beginning of the domestic violence section, respondents are read an additional statement informing them that the subsequent questions could be sensitive and reassuring them of the confidentiality of their responses. The domestic violence module is then implemented only if privacy is obtained. For each one of the 18 countries, we merge the women dataset with the household one, so that each woman is attributed to her corresponding household. We then match individual-level data with Murdock's Ethnographic Atlas, assigning to each individual in the DHS the ancestral characteristics of her ethnic group in the Atlas. We end up with 96,077 women in the sample.

Attitudes towards violence. We exploit a set of attitudinal measures that reflect a combination of attitudes towards domestic violence and attitudes towards women. The respondents are asked whether a husband is justified in hitting or beating his wife under different circumstances: the wife goes out without telling him; the wife neglects their children; the wife argues with him; the wife refuses to have sex with him; the wife burns the food. The women sample includes 28 African countries, while the male sample $27 .{ }^{9}$

\footnotetext{
${ }^{8}$ The survey rounds in the respective countries are: BF6 (Burkina Faso, 2010), CD6 (Congo Democratic Republic, 2013-2014), CI6 (Cote d'Ivoire, 2011-2012), CM6 (Cameroon,2011), GA6 (Gabon, 2012), GH5 (Ghana, 2008), KE5 (Kenya, 2008-2009), ML5 (Mali, 2006), MW5 (Malawi, 2006), MZ6 (Mozambique, 2011), NG6 (Nigeria, 2013), NM6 (Namibia, 2013), RW6 (Rwanda, 2010), SL6 (Sierra Leone, 2013), TG6 (Togo, 20132014), UG6 (Uganda, 2011), ZM5 (Zambia, 2013-2014), ZW6 (Zimbabwe, 2010-2011).

${ }^{9}$ The survey rounds in the respective countries are: BF6(Burkina Faso, 2010), BJ6 (Benin, 2011-2012), CD6(Congo Democratic Republic, 2013-2014), CG6(Congo-Brazzaville, 2011-2012), CI6(Cote d'Ivoire, 2011-2012), CM6(Cameroon,2011), GA6(Gabon, 2012), GH5(Ghana, 2008), ET6(Ethiopia, 2011), GN6(Guinea, 2012), KE5(Kenya, 20082009), LB6(Liberia, 2013), LS5(Lesotho, 2009), ML5(Mali, 2006), MW5(Malawi, 2006),
} 
After having assigned each individual in the DHS to his/her corresponding ethnic group in the Ethnographic Atlas, we have 266,657 observations for women and 120, 099 for men.

\subsection{Murdock's Ethnographic Atlas and matching with DHS}

Our second data source is the Ethnographic Atlas, a worldwide ethnicitylevel database constructed by George Peter Murdock, which collects ethnographic information for 1,267 ethnic groups and contains over one hundred ethnographic variables taken from societies prior to industrialization. We use the Atlas to combine individual level data from contemporary Africa with information on the ancestral ethnicities of respondents. Matching the DHS with the Ethnographic Atlas requires the construction of a concordance of ethnicities, since names of ethnic groups in the DHS do not always coincide with the ones in the Atlas. Overall, we have 717 ethnicities in the DHS and we are able to match 315 of them. Our matching procedure follows and adapts Michalopoulos, Putterman and Weil (2014). ${ }^{10}$ In order to reconcile the ethnic affiliation in the DHS with the one in Murdock's Atlas, we consider seven possible methods and we order them on the basis of their accuracy. Then, following this ordered list, we adopt the first method that

MZ6(Mozambique, 2011), NI6(Niger, 2012), NG6(Nigeria, 2013), NM6(Namibia, 2013), RW6(Rwanda, 2010), SL6(Sierra Leone, 2013), SN6(Senegal, 2010-2011), SZ5(Swaziland, 2006-2007), TD4(Chad, 2004), TG6(Togo, 2013-2014), UG6(Uganda, 2011), ZM5(Zambia, 2013-2014), ZW6(Zimbabwe, 2010-2011). Niger (NI6) is not included in the male sample because data on religion, which we include in all regressions as a control, is not collected for men.

${ }^{10}$ Even though in our matching procedure we follow Michalopoulos, Putterman and Weil (2014), we make some changes. First of all, they do not distinguish between Ethnologue and the Joshua Project, but they devise three different matching techniques which use data on ethnicities' names from either Ethnologue or the Joshua Project: (i) DHS and Murdock names are alternative names according to Ethnologue or the Joshua Project; (ii) a name in Murdock's Atlas is listed as a macro ethnicity that includes the ethnicity in the DHS, according to Ethnologue or the Joshua Project; and (iii) an ethnicity in Murdock's Atlas is part of a larger ethnicity in the DHS, according to either Ethnologue or the Joshua Project. Since this distinction is not relevant for our purposes, we do not separate these three cases, while we consider Ethnologue and the Joshua Project as separate sources. Secondly, Michalopoulos, Putterman and Weil mention "other sources" in the list of their matching strategies, including also Wikipedia in this category. Given that Wikipedia allows us to match a significant number of observations, we decide to list it as a separate source. Finally, we introduce a new source, referred to as "two sources" in Table 1. More specifically, when the available information is ambiguous, we use two sources together to achieve a concordance between the DHS and Murdock names. 
allows to achieve a match between the two datasets. Table 1 illustrates all the matching strategies, with the number and the share of observations and ethnicities that are matched using each strategy.

\section{[Insert Table 1]}

The easiest case is the one in which the name of the ethnicity in the DHS is exactly the same as the one used by Murdock. Unfortunately we are able to directly match only 18.1 percent of the DHS ethnic groups, corresponding to 32.9 percent of the observations. When direct matching is impossible, we use the dataset constructed by Nunn and Wantchekon (2011), which provides a concordance between the ethnicities in the Afrobarometer and those in the Ethnographic Atlas. An example is the DHS ethnicity "Urhobo", which is included among the Afrobarometer ethnic groups in Nunn and Wantchekon's (2011) dataset, where it is associated to the ethnic group that appears as "Isoko" in the Atlas. Using this approach, we match 6.6 percent of the DHS ethnicities, corresponding to 10.9 percent of the observations in our sample. The third method relies on Ethnologue, a catalogue of more than 6700 languages spoken in 228 countries. Three different cases are possible: (i) DHS and Murdock names are listed as alternative names by Ethnologue; (ii) a name in Murdock's Atlas is listed as a superset of the ethnicity in the DHS, i.e. it is a macro category that includes also the ethnicity in the DHS; and (iii) a name in Murdock's Atlas is a subset of a DHS ethnic group, i.e., it is a smaller ethnic group which is included in a larger ethnicity. Michalopoulos, Putterman and Weil (2014) keep these three approaches separate. However, since this distinction is not relevant for our purposes, we combine these three categories into a single category, referred to as Ethnologue. For instance, the DHS ethnic group "Ndola" can be called also "Ndoola", "Njoyane", "Nundoro" or "Ndoro". Since the last one appears in the Ethnographic Atlas, we are able to match it with the DHS ethnicity of interest. Overall, 12.3 percent of the ethnicities are matched using Ethnologue, which accounts for 14.3 percent of the observations. The fourth method uses data on alternative ethnicity names from the Joshua Project and we can have the same three cases described for Ethnologue. For example, according to the Joshua Project, the DHS name "Sheko" is an alternate name of "Shako", an ethnicity that is present in Murdock's Atlas. The Joshua Project allows us to match 1.4 percent of the ethnicities and 0.5 percent of the observations in the sample. When the ethnicity name reported in the DHS does not appear neither in Ethnologue nor in the 
Joshua Project, we check whether Wikipedia mentions possible alternate names for that ethnic group. For instance, the DHS name "Gourmatché" is listed as an alternative name for "Gurma", present in the Ethnographic Atlas. Overall, 2.9 percent of the DHS ethnic groups are matched with the Atlas using Wikipedia, for a total of 8 percent of the observations. In some cases, two sources are needed in order to achieve a concordance between the DHS and Murdock names. For example, "Mandingue" is a DHS ethnicity which has some alternate names according to Ethnologue ("Mande", "Mandingo", "Mandinka"). However, none of them appears in Murdock's Atlas, while "Mandinka" is listed by Nunn and Wantchekon (2011) within the Afrobarometer names and it is associated with "Malinke" in the Atlas. 1.8 percent of the DHS ethnicities are matched with the Ethnographic Atlas using two sources, for a total of 6.5 percent of the observations. Finally, we employ two additional sources (peoplegroups.org and zyama.com) when the available information is ambiguous and leaves some doubts on the reliability of the matching. They allow to match 0.8 percent of the DHS names, corresponding to 0.1 percent of the observations.

Overall we are able to match 73.2 percent of the DHS observations: a total of 386, 802 individuals are matched to a Murdock's Atlas group and assigned ancestral characteristics of the corresponding ethnicity in the Ethnographic Atlas.

\subsection{Descriptive statistics}

Appendix Table A.1 lists the variables we use in our empirical analysis and their sources. Section A2 and Section A3 of the Appendix provide a detailed description of the construction procedure for dependent and independent variables, respectively.

\section{Domestic violence}

\section{[Insert Table 2]}

Table 2 reports summary statistics. The indicator variable 'Violence attitude' takes value 1 if the respondent believes that violence is acceptable in at least one out of five circumstances included in the survey: going out without telling the husband; neglecting the children; arguing with the husband; refusing to have sex with the husband; and burning the food. The first row of Table 2 shows that 46 percent of women justify wife beating in at least one circumstance, while the corresponding figure for men is 34 percent. As an 
alternative measure, we construct the 'Violence attitude index' as the sum of the circumstances in which the respondent thinks it would be acceptable for a man to beat his wife. The average number of episodes in which spousal violence is justified is 1.3 (out of 5 ) for female respondents and 0.76 for male ones. We also report the fraction of women and men justifying wife beating in each of the five circumstances included in the 'Violence attitude index'. The circumstance under which both female and male respondents justify more husband's abuses is when the wife neglects the children: 32 percent of women believe that violence is acceptable in this case, while this share reduces to 21 percent for men. Almost one out of three women justifies spousal violence if the wife argues with the husband and a similar share of female respondents believes that wife beating is acceptable when the wife goes out without telling the husband. ${ }^{11}$ Note that men's attitudes towards spousal violence may be affected by underreporting, because men could hinder their true views in order not to look bad in front of the interviewer, although this may hold also for women.

In the bottom part of Table 2 we examine variables that capture the actual violence experienced by female respondents. Note that the sample size is smaller because this module is administered by the DHS only in 18 African countries, as we discussed in Section 3.1. According to our first indicator variable, 'Violence ever', 29 percent of women have experienced either sexual or physical violence since the age of 15 . In the latest twelve months prior to the survey ('Violence last year'), the fraction is 22 percent. The information on the occurrence of each episode of spousal violence allows us to also construct an indicator for the intensity of violence. This variable is computed as the sum of different types of physical and/or sexual aggression to which the woman has been exposed ever since age 15 ('Violence index ever') and during the twelve months prior to the survey ('Violence index last year'). This index ranges from 0 to 6 and it has a mean of 0.63 when focusing on violence ever experienced and of 0.46 when considering the past year.

Overall, the descriptive patterns in Table 2 suggest that domestic violence is relatively widespread in contemporary Africa. This is even more striking when considering that these figures are likely affected by underreporting.

\footnotetext{
${ }^{11}$ Domestic violence seems to be slightly less accepted by both women and men when the wife refuses to have sex with the husband and when she burns the food, even if the share of individuals justifying violent behaviors under these circumstances remains worrisome.
} 


\section{Ancestral characteristics}

[Insert Table 3]

Table 3 reports summary statistics on the long term cultural and economic variables that we employ in the analysis. In this table we use the sample of all women with data on domestic violence attitudes; summary statistics of ancestral characteristics for the (smaller) sample with information on actual violence are reported in Appendix Table A.2. After matching modern ethnicities in the DHS with ancestral tribes in the Ethnographic Atlas, we assign to each respondent the characteristics of his/her corresponding ethnic group in Murdock's dataset. Murdock's Atlas contains information on production activities prior to industrialization. In our African sample, agriculture was the main source of subsistence prior to industrialization: 97 percent of respondents' ancestors mainly relied on agriculture, while the average share of subsistence provided by agricultural activities was 62 percent (variable 'Dependence on agriculture'). Only 6 percent of women's ancestors in our sample traditionally used the plough. ${ }^{12}$. The Ethnographic Atlas lists four other production activities (gathering, hunting, fishing and animal husbandry) and the share of subsistence they provided is, respectively, .06, $.09, .09$ and .19 .

In addition, the Atlas reports for each production activity the following gender participation categories: males only, males appreciably more; equal participation; females appreciably more; and females only. Using this information, we construct an indicator variable equal to one if there was equal gender participation, or if women contributed more than men or if women were the only participants to the production activity, and zero otherwise. ${ }^{13}$ Descriptive statistics reported in Table 3 suggest that gathering and agriculture were characterized by equal gender participation or higher female participation compared to men's (recall that for the vast majority of our

\footnotetext{
${ }^{12}$ In Murdock's data, ethnicities are classified into one of the following mutual exclusive categories: the plough was absent; the plough existed but it was not aboriginal; the plough was aboriginal and found in the society prior to contact. Using this categorization, we construct an indicator variable equal to 1 if the society used the plough (whether aboriginal or not) and zero otherwise.

${ }^{13}$ The original classification in Murdock's Atlas makes a distinction between "differentiated but equal participation" and "equal participation, no marked differentiation". Since this distinction is not relevant for our purpose, we combine these two categories. If the activity is present but participation by gender is not specified, or if the activity is absent, our variable takes a missing value.
} 
sample we have plough negative agriculture). Animal husbandry was practiced by both men and women, while fishing was a predominantly male activity. ${ }^{14}$

We next focus on a set of variables describing ancestral marriage and living arrangements. 92 percent of women have ancestors whose mode of marriage was characterized by brideprice, that is a payment in monetary terms or in kind to the bride's family (variable 'Brideprice'). ${ }^{15} .22$ percent of women's ancestors practiced endogamy, the custom of marrying exclusively within a specific ethnic or social group. The prevalence of 'stem family', i.e., an arrangement where two generations cohabit, is 25 percent. Polygyny (a form of plural marriage in which a man is allowed to have more than one wife) is an ancestral characteristic of 97 percent of the respondents, and virilocality (a marriage arrangement according to which a married couple resides with or near the husband's parents) was prevalent for 85 percent of them.

We then provide descriptive evidence also for alternative types of settlements (sedentary, nomadic, compact and isolated): the vast majority of women's ancestors lived in sedentary settlements. The last rows of Table 3 report summary statistics for inheritance norms adopted by ancestral societies. Gender equality in land inheritance, with land equally divided between daughters and sons, was practiced in only 5 percent of the cases. In addition, 14 percent of women's ancestors followed a matrilineal descent system, meaning that an individual's descent was traced through the mother and her maternal ancestors, and a man's property was inherited by his sister's sons instead of his own children. Finally, the last row of Table 3 suggests that primogeniture was applied to land inheritance in 63 percent of the cases, at least before the economy opened up to industrialization.

Summary statistics for the socioeconomic controls that we use in our regressions are reported in Appendix Table A.3. The first panel of this table refers to the sample of all African countries for which data on attitudes towards domestic violence are available, while the second panel refers to the 18

\footnotetext{
${ }^{14}$ We don't report female participation in hunting in the table because the mean is exactly zero.

${ }^{15}$ The dummy 'Brideprice' is equal to 1 if the prevalent mode of marriage prior to industrialization was characterized by brideprice or wealth to bride's family, bride service to bride's family or token brideprice in the definition of Murdock's Atlas.
} 
African countries where data on actual violence experienced are collected. ${ }^{16}$

\section{Empirical strategy and results}

\subsection{Empirical model}

We estimate the following regression:

$$
\text { Violence }_{i g c}=\alpha_{c}+\beta \cdot \text { Ethno }_{g}+\gamma X_{\text {igc }}+\epsilon_{i g c}
$$

where Violence $_{i g c}$ is the outcome of interest for individual $i$ from ethnicity $g$ in country $c$. This is the 'actual' violence dummy (or index) when we consider violence episodes experienced by the woman, and the violence 'attitudes' dummy or index when we focus on women's and men's attitudes. ${ }^{17}$

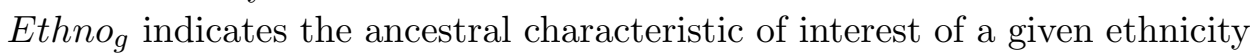
$g$, derived from Murdock's Ethnographic Atlas. It can refer to ancient living arrangements, distinct types of production activities, different marriage patterns or different inheritance norms. $X_{i g c}$ is a vector of individual controls including woman's and partner's age and years of education, a dummy equal to one if the woman is currently working, the number of children ever born and the household size, a wealth index, a dummy for urban residence and a set of religion dummies. ${ }^{18} . \alpha_{c}$ is a vector of country fixed effects. Standard errors are clustered at the ethnicity level.

When the outcome is binary, we estimate the regression using a linear probability model (OLS) and Probit. When the dependent variable is a count variable (i.e., in the case of the violence index), we use ordinary least squares (OLS) and a Poisson model. We report OLS estimates in the main text, and refer the reader to Section 5 for the Probit and Poisson models.

\footnotetext{
${ }^{16}$ For the attitudes regressions, the female sample includes 28 countries, while the male sample includes 27 countries.

${ }^{17}$ In Appendix A.2 we provide a detailed description of how these different measures of violence are constructed.

${ }^{18}$ The DHS wealth index is an indicator of household's economic status. It is a continuous variable and it is constructed using principal component analysis, starting from household's assets.

Angelucci (2008), evaluating the impact of the program Oportunidades on domestic violence and alcohol abuse, observes that violence increases with woman's age but with diminishing marginal returns. In order to check whether the relationship between age and violence is nonlinear, we included woman's and partner's age squared. Since the coefficients of woman's and man's age squared were typically insignificant, we decided to include only age, without its square, in our final specification.
} 


\subsection{Current economic correlates of domestic violence}

Table 4 shows the individual and contemporaneous correlates of various measures of violence against women.

\section{[Insert Table 4]}

The results are quite meaningful. Violence (actual and tolerated) decreases with age and education both of the woman and of the partner and the propensity to justify husband's abuses is also negatively correlated with wealth. This may reflect the fact that wealthier and more educated families are subject to less stressful conditions and this makes them less likely to resort to violence, or it may simply reflect preferences for exerting violence that negatively correlate with education and wealth. Household size and the number of births that the woman had are positively correlated with violence, probably due to the stress of supporting large families. Other explanations are also possible, though, such as the presence of unobserved factors correlated with household size, or reverse causality if the violence was motivated by an attempt on behalf of the man to induce the woman to have more children.

In urban areas violence occurs more frequently but it is less justified by men and women. Urbanization is one of the few variables for which the results on actual violence reported and on attitudes do not go in the same direction. Reporting bias could be one interpretation of this discrepancy: urban women may be more open to revealing that they have been beaten, while at the same time being less accepting of it. Another possibility is that residents of urban areas in Africa are experiencing a faster transition from traditional norms that considered gender based violence acceptable to modern ones that condemn it, and that the dichotomy between tradition and modernization in the short run gives rise to increasing levels of violence by men whose identity is challenged by the new systems of beliefs.

The occurrence of violence (but not acceptance) is increasing when women work. This may be associated with women having a stronger bargaining power within the family and therefore posing a potential threat to the dominating role of the husband, consistent with the 'male backlash' theory. Note that the variable 'Working' captures whether the woman under cosideration is currently working. Below we will investigate how the economic role of women in the past generated cultural attitudes related to current domestic violence. 
We now move to examine how past socioeconomic arrangements may affect current level of violence due to the persistence of attitudes and cultural values. All the variables listed in Table 4 are included as controls in every regression we present in the next sections but their coefficients are not reported for brevity. The coefficients on the individual controls are very stable.

\subsection{Cultural determinants of domestic violence}

\subsubsection{Economic value of women}

Table 5 reports our results on how ancestral characteristics pertaining to the economic value of women affect contemporary violence. Each panel in the table focuses on a different explanatory variable and reports the coefficient on the variable of interest (other controls are included but not reported), the number of observations, the R-squared and the mean of dependent variable in the subsample considered, to help assess the magnitude of the estimated effect in relation to the mean.

\section{[Insert Table 5]}

In the first regression we consider the economic value of the woman as implicit in marriage payments. The dummy 'Brideprice' is equal to 1 if the prevalent mode of marriage of the respondent's ethnic group prior to industrialization was characterized by brideprice, i.e., if the husband had to make a payment to obtain a wife, as opposed to receiving a dowry or not making any payment. ${ }^{19}$ More than 90 percent of individuals in our sample have ancestors who practiced brideprice.

Anthropologists, demographers and economists have advanced various theories to explain under which conditions brideprice, instead of dowries, is more likely to prevail (Botticini, 2003). According to Becker (1981), marriage payments clear the market when sex ratios are unbalanced. Therefore, in a society where women are less numerous, a man will pay a brideprice in order to attract a bride. Goody (1973) instead claims that dowry is a form of inheritance from the bride's parents to the bride. In societies with dowries, sons receive inheritance, while daughters receive wealth transfers from their parents in the form of dowries at the time of marriage. According to this theory, dowries are more likely to prevail in stratified societies, characterized

\footnotetext{
${ }^{19}$ In terms of Murdock's classification, our variable includes brideprice or wealth to the bride's family, bride service to the bride's family and token bride price.
} 
by higher wealth and status inequality. On the contrary, brideprice is more likely to emerge where there is little social and economic stratification, and this could explain why brideprice is more common than dowries in many African societies. Finally, Boserup (1970) argues that brideprice is more likely to emerge in economies in which agriculture is based on shifting hoe cultivation, such as most African societies. In this context, women are actively engaged in agricultural activities and, by paying a brideprice to the bride's family, the groom acquires the right to the bride's labor force. Thus, on the one hand, brideprice could be interpreted as an explicit recognition of women's value. On the other hand, it could limit women's independence, due to shame and fear deriving from breaking a marital relationship and returning to their parental house, without being able to repay the brideprice (Ansell, 2001). ${ }^{20}$

Our results support the first argument. Having brideprice in the past is associated with a decrease of 11.5 percentage points in the probability of ever being exposed to spousal violence. This is a very large effect considering that the average probability of violence in our sample is 27.1 percent. When we use as dependent variable the violence index (column 2), which counts the number of violence episodes to which the woman has been subjected, the coefficient on brideprice is -0.35 , significant at the 1 percent level. Interestingly, in line with the argument about the value of wives, the effect of lower actual violence seems to be driven by a lower acceptance of wife beating on the part of the man: in brideprice-paying societies the likelihood of justifying a husband's choice to beat his wife declines by 6 percentage points for the male sample (column 5) and also the number of circumstances in which beating is justified by men (column 6 ) is significantly lower.

The remaining panels of table 5 refer to the economic value of women as determined by traditional modes of production. We construct a binary variable equal to one if the society used the plough (whether aboriginal or not) and zero otherwise. ${ }^{21}$ The coefficients of the variable 'Plough' in columns 1 and 2 of panel B indicate that the descendants of societies that practiced plough agriculture experience a higher degree of violence today. Women whose ancestors practiced plough agriculture are 13.2 percentage points more likely to be victims of husband's aggressions. This is a large

\footnotetext{
${ }^{20}$ In line with this argument, Horne, Nii-Amoo Dodoo and Dodua Dodoo (2013) conduct a vignette experiment in Ghana's Volta region and observe that when a man has paid a brideprice, he gains the right to the woman's reproductive services. In other words, after brideprice payment, wives defer to their husbands for reproductive choices.

${ }^{21}$ Note that in our sample very few ethnicities used the plough.
} 
effect, representing a 50 percent increase over the mean.

We next consider the role of overall dependence on agriculture, as opposed to hunting, fishing, gathering and pastoralism. The idea is that in economies based on agriculture, especially without the plough like in most of our sample, women could participate more in the labor force and develop a more equal status in society and in the family, and this may generate norms of greater respect for women, similar to what we found above for brideprice. Indeed, the qualitative pattern of results in panel $\mathrm{C}$ of table 5 is consistent with this interpretation: the dummy 'Agriculture main source' displays negative coefficients in all regressions, although it is only significant when we consider the violence attitude index for the female sample (column 4).

In the next five panels of Table 5, instead of relying on dichotomous variables, we employ continuous indicators capturing the share of total production accounted for by various activities. For example, the variable ' $D e$ pendence on agriculture' in panel D indicates the share of total subsistence activities accounted for by agriculture in the respondent's ethnic group. This variable is insignificant, although with the expected sign. Dependence on gathering reduces the likelihood and intensity of violence experienced by women (columns 1-2 of panel E), consistent with the fact that gathering is the activity with the highest share of female labor force participation relative to men (see Table 3). Dependence on fishing and hunting, which are practiced almost exclusively by men in our sample, are associated with more violence towards women today. We find no correlation between dependence on animal husbandry and spousal violence.

Finally, following Alesina, Giuliano and Nunn (2013) we consider land suitability for plough cultivations as an exogenous determinant of whether the plough is used and of whether women traditionally engaged in farming. In panel I of Table 5 we regress our domestic violence outcomes on land suitability for plough-positive and plough-negative crops. ${ }^{22}$ The two measures for plough-positive and plough-negative crops have been constructed following Alesina, Giuliano and Nunn (2013), using the information on the suitability of a location for cultivating different types of crops collected in the FAO's Global Agro-Ecological Zones (GAEZ 2002). In particular, we identify the land inhabited by each of the ethnic groups in the Ethnographic Atlas, then we use all land within 200 kilometers of an ethnic group's cen-

\footnotetext{
${ }^{22}$ Notice that these variables are not collinear because a given area may be suitable for plough positive crops only, plough negative only, for both types or for neither one.
} 
troid and measure the amount of land within this area that can grow each of the cereal crops that comprise our measures of land suitability. Wheat, barley and rye are plough-positive crops, while sorghum, foxtail millet and pearl millet are plough-negative ones. ${ }^{23}$ So the variables 'Plough-positive crops' and 'Plough-negative crops' capture the average suitability for each type of crop, normalized by the overall suitability for cultivation in general. When considering the relationship between land suitability and domestic violence, we observe that having an ancestral environment that was more suitable to cultivate plough-positive crops is associated with a higher female acceptability of partner violence, while no significant relationship emerges for male attitudes towards partner violence and actual violence experiences. When the environment was better able to cultivate plough-negative crops, then the number of episodes in which women think violence would be acceptable is higher, while no significant effect is found on other domestic violence variables.

Overall, the results in Table 5 are very consistent with our two hypotheses. First, when women are more economically valuable (e.g., because men have to pay for them and/or they are productive for the economic structure of the family) they are less subject to intrafamily violence and this type of violence is considered less acceptable. Second, ancestral characteristics of society which led to a different economic role of women determine cultural attitudes that persist even today when socioeconomic conditions have evolved. ${ }^{24}$

\subsubsection{Marriage patterns}

We next consider another set of cultural determinants of the propensity to violence, arising from distinct marriage patterns among ethnic groups in pre-colonial times.

\section{[Insert Table 6]}

\footnotetext{
${ }^{23}$ As in Alesina, Giuliano and Nunn (2013), we assume that land suitability for different types of crops provided by GAEZ is an unbiased measure of relative historical suitability. Nunn and Qian (2011) show that there is a positive correlation between a country's suitability for potato cultivation today and historical potato production.

${ }^{24}$ To explore the role of economic factors further, we tested whether customary inheritance practices of one's ethnic group affect domestic violence. In particular, we focused on equal transmission of land inheritance to daughters and sons, on matrilineal inheritance and on primogeniture (as coded in the Ethnographic Atlas). None of these variables was significantly associated with domestic violence in our sample. Results are available upon request.
} 
Panel A of Table 6 shows the impact of endogamy, i.e., the practice of marrying within a specific social or ethnic group, on spousal violence. We find that being from an ethnicity that was traditionally endogamous is positively associated with violence experienced, increasing the likelihood of ever being victim of violence by 6.9 percentage points, a 26 percent increase over the mean. This is accompanied by a positive and significant effect on the reported male acceptability of violence towards women. We can think of two possible interpretations. One is that ethnicities which practiced endogamy were less open to new ideas and in some respect more 'backward'. The second interpretation is that beating a wife of a different ethnic group may bring about retaliation across ethnicities. The possibility of retaliation and open conflict with other ethnic groups may have acted as a deterrent to domestic violence in societies practicing exogamy, in a similar way in which it may deter inter-ethnic conflict (Fearon and Laitin, 1996).

The second marriage arrangement we consider is the stem family, which is a small extended family in which two generations cohabit in the same homestead, as one son stays at the parental house with his wife and children. Columns 3 to 6 of panel B show that where the stem family was socially predominant in the past, both men and women tend to be less favorable to violence. This result is consistent with the evidence from Spain provided by Tur-Prats (2015). She argues that co-residence with another woman (the mother-in-law) increased the productive role of the wife, since it decreased the burden of domestic work for the latter, thus freeing up time for farming work. The same explanation can rationalize our results.

Another widespread social institution in Sub-Saharan Africa prior to industrialization was polygyny, a custom that allows men to have multiple wives. $^{25}$ Interestingly, there seems to be no correlation between intimate partner violence and polygynous unions (panel C). The lack of an effect may result from two contrasting forces. On the one hand, to the extent that having more than one wife indicates a less progressive orientation and a lower consideration of women's status, one would expect to see an increase in violence associated with polygyny. On the other hand, some of the motives that typically instigate violence against one's wife may be alleviated by the presence of other wives. For example, if the inability of the first wife to deliver a son is compensated for by a second wife who delivers one, this may

\footnotetext{
${ }^{25}$ While we do not investigate the origins of polygyny in this paper, Goody (1973) argues that "the reasons behind polygyny are sexual and reproductive rather than economic and productive" (ibidem, p.189). For an empirical analysis of polygyny in Africa, see Fenske (2015).
} 
reduce the husband's propensity to beat the first wife. ${ }^{26}$

Finally, we consider the role played by customary residence patterns upon marriage. For the majority of ethnic groups in our sample (85 percent of respondents), traditional norms prescribe that upon marriage the couple resides in the same village or clan territory of the husband and/or of his family (patrilocal or virilocal residence). In panel $\mathrm{D}$ we find no evidence that virilocal residence affects domestic violence incidence or attitudes.

\subsubsection{Types of settlements}

Table 7 focuses on traditional living arrangements. We include three dummies corresponding to the three different types of settlements prior to industrialization -nomadic, isolated and compact- while the omitted category is sedentary settlements. ${ }^{27}$

\section{[Insert Table 7]}

We find that violence tends to be higher in nomadic communities, that women tend to justify more husband's abuses in isolated settlements, while men whose ancestors lived in compact settlements are less prone to justify wife beating today. These results are consistent with several non-exclusive interpretations. One is that nomadic and isolated settlements represent less developed organizational patterns and that this feature correlates with

\footnotetext{
${ }^{26}$ Milazzo (2014) finds that women with a first-born daughter are significantly more likely to be involved in a polygynous union, compared to women with a first-born son. She also observes that the probability of being in a polygynous relationship when having a first born daughter is higher for first-rank wives, while she finds no effect for higher rank wives, confirming that husbands may choose to marry another woman because the first had a daughter.

${ }^{27}$ In Murdock's Atlas, ethnicities are grouped into different categories based on settlements patterns: nomadic or fully migratory; seminomadic; semisedentary; compact but impermanent settlements; neighborhoods of dispersed family homesteads; separated hamlets forming a single community; compact and permanent settlements; and complex settlements. Starting from this classification, we create a dummy 'Nomadic' equal to one if the traditional settlements patterns were nomadic or seminomadic, a dummy 'Isolated', equal to one when ancestral settlements were characterized by neighborhood of dispersed family homesteads, a dummy 'Compact', which refers to those ethnic groups who had compact but impermanent settlements or compact and relatively permanent settlements, and a dummy 'Sedentary', including semisedentary settlements, neighborhoods of dispersed family homesteads, separated hamlets forming a single community, compact and relatively permanent settlements and complex settlements, which is used as the omitted category.
} 
domestic violence. Another possible interpretation is that societal protection of women is more difficult within these types of living arrangements. The latter interpretation is consistent with the social control theory by Gelles (1983) and Gelles and Straus (1988) since in these types of settlement social control against violence is likely to be low.

\subsection{Heterogeneous effects}

In Table 4 we found that the occurence of violence (but not an attitude of acceptance) increases when women are currently employed. We next consider whether this effect is the same for all societies or if it is larger for ethnic groups whose women traditionally contributed less to the family income. Underlying our hypothesis are the theories that point to the importance of men's "breadwinner's culture" as a mediating factor in whether women's resources are empowering or detrimental as a trigger to violence (see, e.g., Atkinson et al., 2005). This part of our analysis is also in the spirit of Cools and Kotsadam's (2015) and Tur-Prats' (2016) recent empirical exercises. We investigate the above question by estimating the following regression:

$$
\begin{aligned}
\text { Violence }_{i g c}= & \alpha_{c}+\delta \cdot \text { Working }_{i g c}+\beta \cdot \text { Ethno }_{g}+ \\
& +\rho \cdot \text { Working }_{i g c} \cdot \text { Ethno }_{g}+\gamma X_{i g c}+\epsilon_{i g c}
\end{aligned}
$$

where Violence $_{i g c}$ is the outcome of interest for individual $i$ from ethnicity $g$ in country $c$. As before, this is the 'actual' violence dummy (or index) when we consider violence episodes experienced by the woman, and the violence 'attitudes' dummy (or index) when we focus on women's and men's attitudes. Working igc is a dummy equal to one if the woman is currently working, while Ethno $g$ indicates the ancestral characteristic of interest of the ethnicity $g$ to which the individual belongs. It refers to ancestral features derived from Murdock's Ethnographic Atlas, which are related to gender roles in the past and women's traditional contribution to the family income. $X_{i g c}$ is a vector of individual controls and $\alpha_{c}$ is a vector of country fixed effects. ${ }^{28}$ Standard errors are clustered at the ethnicity level. Results are in Table 8.

\section{[Insert Table 8]}

\footnotetext{
${ }^{28} X_{i g c}$ includes woman's and partner's age and years of education, the number of children ever born and the household size, a wealth index, a dummy for urban residence and a set of religion dummies.
} 
Each panel in the table shows the coefficients of the variable 'Working', of the cultural characteristic of interest and of the interaction between these two variables. It also displays the p-value of the test that sum of the coefficients of the variable 'Working' and the interaction term is equal to 0 , i.e., that $\widehat{\delta}+\widehat{\rho}$ in (2). Finally, as for the other tables, we report the number of observations, the R-squared and the mean of dependent variable in the subsample considered. Although we only display three coefficients for each regression, we always include the individual controls listed before and country fixed effects, as in equation (1).

Panel A of table 8 shows that, in societies that did not practice brideprice in pre-colonial times, women who are currently employed are more likely to be victims of domestic violence $(\widehat{\delta}>0)$. Interestingly, this effect is strongly reduced in those societies that were characterized by brideprice in the past: the coefficient of the interaction term 'Working*brideprice' $(\widehat{\rho})$ is negative and significant. A possible reason is that ancestral practices that may have induced a higher consideration of the economic value of women (e.g., brideprice) make women's current working status more acceptable. When considering women's and men's attitudes towards wife beating, we find no significant heterogenous effects.

In panel $\mathrm{B}$ we examine the role of plough agritulture. When considering actual violence (columns 1 and 2), we observe that the coefficient of the dummy 'Working' is positive and significant, while the coefficient of the interaction term between 'Working' and 'Plough' is negative and significant, suggesting that violence against women increases if they work, but this effect is not present in ethncities that used the plough. Albeit counter-intuitive, this result might be affected by the fact that very few ethnicities used the plough in our sample.

We next interact the variable 'Working' with the overall dependence on different production activities in ancestral societies. In general, the interaction term is insignificant in panels $\mathrm{C}$ to $\mathrm{H}$, with the exception of panel $\mathrm{E}$, where we consider society's dependence from gathering. While female employment is associated with higher probability and intensity of violence in societies that did not rely on gathering $(\widehat{\delta}>0$ in columns $1-2)$, in ancestral reliance on gathering reverses this effect $(\widehat{\rho}<0)$. Recall that gathering is the activity with traditionally the highest share of female labor force participation (see Table 3). Then this result again suggests that familiarity with women's productive role in pre-colonial times reduces possible intra-family tensions associated with women's work.

Finally, in panels I to L we interact the variable 'Working' with some fea- 
tures related to marriage patterns in pre-colonial times. The only significant heterogeneous effects are found for polygyny (panel K). In non-polygynous societies, working status of the woman is associated with less acceptability of domestic violence $(\widehat{\delta}<0)$, while in polygynous ones this negative effect is mitigated $(\widehat{\rho}>0)$.

\section{Robustness checks}

We test the robustness of our results along several dimensions. First we experiment with different estimation methods for (1). In Appendix Tables A.4 to A.6 we alternatively use a Probit model when the outcome is a dummy variable (corresponding to columns 1, 3 and 5 of the tables) and a Poisson model when the dependent variable is a count variable (i.e., in the case of the violence indices used in columns 2, 4 and 6). For Probit estimates we report marginal effects, while for Poisson models we report incidence-rate ratios, meaning that all coefficients presented in the tables are 'exponentiated' (for example, we report $\exp (\widehat{\beta})$ rather than the estimated coefficient $\widehat{\beta}) .{ }^{29}$ The results in Appendix Tables A.4 to A.6 confirm the OLS results in Tables 5 to 7 .

The second robustness check relates to the different samples used for the analysis of actual violence levels (columns 1-2 in the previous tables) and attitudes towards violence (columns 3 to 6 ). Due to the fact that the survey module on experience of domestic violence was not administered in all DHS countries, our sample for these regressions is smaller than for the attitude regressions. As a robustness check, we therefore re-estimate the impact of historical and cultural legacies on women's and men's attitudes towards spousal violence, restricting the sample to the 18 African countries for which the domestic violence module is available. ${ }^{30}$ By doing so, we are able to test whether our previous results were driven by the larger number of countries for which information on acceptance of violence as a practice is collected.

\footnotetext{
${ }^{29}$ Poisson regression is a form of regression analysis used to model count data. It assumes that the dependent variable follows a Poisson distribution and the logarithm of its expected value can be modeled using a linear combination of unknown parameters.

${ }^{30}$ The DHS survey rounds in the respective countries are: BF6(Burkina Faso, 2010), CD6(Congo Democratic Republic, 2013-2014), CI6(Cote d'Ivoire, 2011-2012), CM6(Cameroon,2011), GA6(Gabon, 2012), GH5(Ghana, 2008), KE5(Kenya, 2008-2009), ML5(Mali, 2006), MW5(Malawi, 2006), MZ6(Mozambique, 2011), NG6(Nigeria, 2013), NM6(Namibia, 2013), RW6(Rwanda, 2010), SL6(Sierra Leone, 2013), TG6(Togo, 20132014), UG6(Uganda, 2011), ZM5(Zambia, 2013-2014), ZW6(Zimbabwe, 2010-2011).
} 
The results, reported in Appendix Tables A.7 to A.9, are very similar to the ones we reported in the main tables. Here we point out only a few differences. First, we find no evidence of a correlation between dependence on hunting and the likelihood that a woman justifies husband's aggression. Second, we no longer find evidence of a relationship between stem family and acceptability of domestic violence. Third, concerning polygyny, when we consider the restricted sample we observe that the number of episodes in which women think violence would be acceptable is lower. Fourth, we find that men whose ancestors lived in nomadic settlements are more likely to justify spousal violence, while this impact was not found in the extended sample. This is consistent with the view that in nomadic environments social protection of women is likely to be lower. Despite these minor differences, our results are largely robust to different definitions of the sample.

Finally, we re-estimated the association between pre-colonial features of society and contemporary violence excluding female employment and number of births from the set of controls, as these are potentially endogenous variables. Our results were essentially unaffected. ${ }^{31}$

\section{Conclusions}

We have investigated the role of individual characteristics as well as ancestral features of individuals' ethnic groups in explaining domestic violence in the African continent. Our conclusions can be summarized in two points.

First, ancient socioeconomic conditions shape social norms about gender roles, family structures and intrafamily violence which persist over time even when the initial conditions change. We have shown how norms about marriage patterns, living arrangements and the productive role of women in ancient times are associated with violence experienced by women and with attitudes towards violence within the family today.

Second, we have focused on how women's economic role may affect violence and found a complex pattern of relationships. On the one hand, in societies where in pre-colonial times women had an active economic role and/or a brideprice was paid upon marriage, men are less prone to violence even today, given the nature of gender roles determined by these past arrangements. On the other hand, we find increases in domestic violence for couples where the woman is currently economically active and independent, i.e., where she may have more bargaining power within the family and pose

\footnotetext{
${ }^{31}$ Results are available upon request.
} 
a threat to the husband. All these results are consistent with the hypothesis of long term persistence of gender norms. 


\section{References}

[1] Aizer, A. (2010). "The Gender Wage Gap and Domestic Violence". American Economic Review, 100(4), 1847-1859.

[2] Alesina, A., Giuliano, P., and Nunn, N. (2013). "On the Origins of Gender Roles: Women and the Plough". Quarterly Journal of Economics, 128(2), 469-530.

[3] Anderson, K. L. (1997). "Gender, Status, and Domestic Violence: An Integration of Feminist and Family Violence Approaches". Journal of Marriage and the Family, 59(3), 655-669.

[4] Anderson, S. (2007). "The Economics of Dowry and Brideprice". Journal of Economic Perspectives, 21(4), 151-174.

[5] Angelucci, M. (2008). "Love on the Rocks: Domestic Violence and Alcohol Abuse in Rural Mexico". The B.E. Journal of Economic Analysis E) Policy, 8(1), 1-41.

[6] Ansell, N. (2001). "Because it's our culture!" (Re)negotiating the meaning of lobola in Southern African secondary schools". Journal of Southern Africa Studies, 27(4), 697-716.

[7] Atkinson, M. P., Greenstein, T. N., and Lang, M. M. (2005). "For Women, Breadwinning Can Be Dangerous: Gendered Resource Theory and Wife Abuse." Journal of Marriage and Family, 67(5), 1137-1148.

[8] Becker, G. (1981). A Treatise on the Family. Cambridge, MA: Harvard University Press.

[9] Bertrand, M., Kamenica, E., and Pan, J. (2015). "Gender Identity and Relative Income within Households". Quarterly Journal of Economics, 130(2), 571-614.

[10] Bloch, F., and Rao, V. (2002). "Terror as a Bargaining Instrument: A Case Study of Dowry Violence in Rural India". American Economic Review, 92(4), 1029-1043.

[11] Boserup, E. (1970). Woman's Role in Economic Development. London, UK: George Allen and Unwin Ltd. 
[12] Botticini, M. (2003). Marriage Payments. In Mokyr, J. (Eds.), Oxford Encyclopedia of Economic History, vol.3. New York, NY: Oxford University Press.

[13] Bowlus, A. J., and Seitz, S. (2006). "Domestic Violence, Employment, and Divorce." International Economic Review, 47(4), 1113-1149.

[14] Carbone-López, K., C. Kruttschnitt and R. Macmillan (2006), "Patterns of intimate partner violence and their associations with physical health, psychological distress, and substance use". Public Health Reports, 121(4), 382-92.

[15] Card, D., and Dahl, G. B. (2011). "Family Violence and Football: The Effect of Unexpected Emotional Cues on Violent Behavior". Quarterly Journal of Economics, 126(1), 103-143.

[16] Cools, S., Kotsadam, A. (2015). "Resources and intimate partner violence in Sub-Saharan Africa". Working Paper.

[17] Dobash, R. P., and Dobash, R. E. (1979). Violence against wives: A case against the patriarchy. New York, NY: Free Press.

[18] Dugan, L., Nagin, D., and Rosenfeld, R. (1999). "Explaining the Decline in Intimate Partner Homicide: The Effect of Changing Domesticity, Women's Status and Domestic Violence Resources". Homicide Studies, 3(3), 187-214.

[19] Duvvury, N., Callan, A., Carney, P., and Raghavendra, S. (2013). "Intimate Partner Violence: Economic Costs and Implications for Growth and Development". Women's Voice, Agency, \& Participation Research Series 2013 N.3, The World Bank, Washington D.C.

[20] Farmer, A., and Tiefenthaler, J. (1997). "An Economic Analysis of Domestic Violence". Review of Social Economy, 55(3), 337-358.

[21] Fearon, J. D., and Laitin, D. D. (1996). "Explaining Interethnic Cooperation". American Political Science Review, 90(4), 715-735.

[22] Fenske, J. (2015). "African polygamy: Past and present". Journal of Development Economics, 117, 58-73.

[23] Fernández, R., Fogli, A., and Olivetti, C. (2004). "Mothers and Sons: Preference Formation and Female Labor Force Dynamics". Quarterly Journal of Economics, 119(4), 1249-1299. 
[24] Gartner, R. and Macmillan, R. (1999). "When She Brings Home the Bacon: Labor Force Participation and the Risk of Spousal Violence Against Women". Journal of Marriage and the Family, 61(4), 947-958.

[25] Gelles, R. J. (1976). "Abused Wives: Why do They Stay?" Journal of Marriage and the Family, 38(4), 659-668.

[26] Gelles, R. J. (1983). An exchange/social control theory. In Finkelhor, D., Gelles, R.J., Hotaling, G.T. and Straus M.A. (Eds.), The dark side of families: Current family violence research. Beverly Hills, CA: Sage, 151-165.

[27] Gelles, R. J., and Straus, M. A. (1988). Intimate violence: The causes and consequences of abuse in the American family. New York, NY: Simon \& Schuster.

[28] Goody, J. (1973). Polygyny, Economy and the Role of Women. In Goody, J. (Eds.), The Character of Kinship. Cambridge, UK: Cambridge University Press.

[29] Goody, J. (1973). Bridewealth and Dowry in Africa and Eurasia. In Goody, J., and Tambiah, S. J. (Eds.), Bridewealth and Dowry. Cambridge, UK: Cambridge University Press.

[30] Heise, L. L. (1998). "Violence Against Women: An Integrated, Ecological Framework". Violence Against Women, 4(3), 262-290.

[31] Heise, L.L., and Kotsadam, A. (2015). "Cross-national and multilevel correlates of partner violence: an analysis of data from populationbased surveys". The Lancet Global Health, 3(6), 332-340.

[32] Horne, C., Dodoo, F. N.-A., and Dodoo, N. D. (2013). "The Shadow of Indebtedness: Bridewealth and Norms Constraining Female Reproductive Autonomy". American Sociological Review, 78(3): 503-520.

[33] Johnson, M. P. (1995). "Patriarchal Terrorism and Common Couple Violence: Two Forms of Violence against Women". Journal of Marriage and the Family, 57(2), 283-294.

[34] Johnson, M. P., and Ferraro, K. J. (2000). "Research on Domestic Violence in the 1990s: Making Distinctions". Journal of Marriage and the Family, 62(4), 948-963. 
[35] Lawson, J. (2012). "Sociological Theories of Intimate Partner Violence". Journal of Human Beahvior in the Social Environment, 22(5), 572-590.

[36] Michalopoulos, S., Putterman, L., and Weil, D. N. (2014). "The Influence of Ancestral Lifeways on Individual Economic Outcomes in SubSaharan Africa". Working Paper.

[37] Milazzo, A. (2014). "Son Preference, Fertility and Family Structure. Evidence from Reproductive Behavior among Nigerian Women". World Bank Policy Research Working Paper 6869, The World Bank, Washington D.C.

[38] Nunn, N., and Qian, N. (2011). "The Potato's Contribution to Population and Urbanization: Evidence from a Historical Experiment". Quarterly Journal of Economics, 126(2), 593-650.

[39] Pollak, R.A. (2004). "An intergenerational model of domestic violence". Journal of Population Economics, 17(2), 311-329.

[40] Thornton, A., Alwin, D. F., and Camburn, D. (1983). "Causes and Consequences of Sex-Role Attitudes and Attitude Change". American Sociological Review, 48(2), 211-227.

[41] Tur-Prats, A. (2015). "Family Types and Intimate- Partner Violence: A Historical Perspective". Working Papers 835, Barcelona Graduate School of Economics.

[42] Tur-Prats, A. (2016). "Domestic Violence and Unemployment: A Gender Identity Perspective". Mimeo, Barcelona Graduate School of Economics.

[43] Wolfgang, M., and Ferracuti, F. (1967). The subculture of violence: Towards an integrated theory in criminology. London, UK: Tavistock Publications.

[44] Women's Advocates Inc. (2002). Domestic violence fact sheet.

[45] World Health Organization (2004). The economic dimensions of interpersonal violence. Geneva: World Health Organization, Department of Injuries and Violence Prevention. 
[46] World Health Organization (2013). Global and regional estimates of domestic violence against women: prevalence and health effects of intimate partner violence and non-partner sexual violence. Geneva: World Health Organization, Department of Reproductive Health and Research. 


\section{Tables}

Table 1: Matching DHS ethnicities to Ethnographic Atlas

\begin{tabular}{lcccc}
\hline \hline & $\begin{array}{c}\text { Number } \\
\text { observations }\end{array}$ & $\begin{array}{c}\text { Percentage } \\
\text { observations }\end{array}$ & $\begin{array}{c}\text { Number } \\
\text { ethnicities }\end{array}$ & $\begin{array}{c}\text { Percentage } \\
\text { ethnicities }\end{array}$ \\
\hline Direct & 174129 & 32.94 & 130 & 18.13 \\
Nunn and Wantchekon (2011) & 57453 & 10.87 & 47 & 6.56 \\
Ethnologue & 75310 & 14.25 & 88 & 12.27 \\
Joshua Project & 2850 & 0.54 & 10 & 1.40 \\
Wikipedia & 42301 & 8.00 & 21 & 2.93 \\
Two sources & 34262 & 6.48 & 13 & 1.81 \\
Other source & 497 & 0.09 & 6 & 0.84 \\
Not matched & 141813 & 26.83 & 402 & 56.07 \\
\hline \hline
\end{tabular}

Table 2: Summary statistics violence measures - attitudes \& actual violence

\begin{tabular}{|c|c|c|c|c|c|c|}
\hline & \multicolumn{3}{|c|}{ Women } & \multicolumn{3}{|c|}{ Men } \\
\hline & Mean & Std. Dev. & $\mathrm{N}$ & Mean & Std. Dev. & $\mathrm{N}$ \\
\hline \multicolumn{7}{|l|}{ Attitudes towards violence } \\
\hline Violence attitude & 0.462 & 0.499 & 255242 & 0.338 & 0.473 & 115013 \\
\hline Violence attitude index & 1.306 & 1.76 & 246053 & 0.76 & 1.337 & 112260 \\
\hline \multicolumn{7}{|l|}{ Violence justified if the wife: } \\
\hline Goes out without telling & 0.299 & 0.458 & 258972 & 0.179 & 0.384 & 117668 \\
\hline Neglects the children & 0.326 & 0.469 & 259716 & 0.21 & 0.408 & 117889 \\
\hline Argues with the husband & 0.301 & 0.459 & 252395 & 0.187 & 0.39 & 114293 \\
\hline Refuses to have sex & 0.237 & 0.425 & 256827 & 0.114 & 0.318 & 117093 \\
\hline Burns the food & 0.161 & 0.368 & 252843 & 0.083 & 0.275 & 114537 \\
\hline \multicolumn{7}{|l|}{ Actual violence experienced } \\
\hline Violence ever & 0.285 & 0.452 & 77821 & - & - & - \\
\hline Violence index ever & 0.63 & 1.235 & 77683 & - & - & - \\
\hline Violence last year & 0.215 & 0.411 & 77719 & - & - & - \\
\hline Violence index last year & 0.461 & 1.083 & 77683 & - & - & - \\
\hline
\end{tabular}

Notes: Source: Murdock's Ethnographic Atlas and Demographic and Health Survey (DHS). Survey weights are always included. Concerning violence attitudes, all DHS African countries with data on domestic violence attitudes are considered. There are 28 countries for the female sample and 27 countries for the male sample. Concerning actual violence, countries with the violence module are considered. The sample is composed by women selected and interviewed for the domestic violence module. Overall, 18 African countries are included. 
Table 3: Summary statistics ancestral characteristics

\begin{tabular}{lccc}
\hline \hline & \multicolumn{3}{c}{ Women } \\
\cline { 2 - 4 } & Mean & Std. Dev. & $\mathrm{N}$ \\
\hline Ethnographic variables & 0.063 & 0.243 & 259651 \\
\hline Plough & 0.965 & 0.184 & 266361 \\
Agriculture main source & 0.618 & 0.123 & 266361 \\
Dependence on agriculture & 0.064 & 0.046 & 266361 \\
Dependence on gathering & 0.09 & 0.061 & 266361 \\
Dependence on hunting & 0.087 & 0.068 & 266361 \\
Dependence on fishing & 0.194 & 0.113 & 266361 \\
Dependence on husbandry & 0.671 & 0.47 & 230396 \\
Female participation agriculture & 0.866 & 0.341 & 117603 \\
Female participation gathering & 0.176 & 0.38 & 147649 \\
Female participation fishing & 0.454 & 0.498 & 168421 \\
Female participation husbandry & 0.921 & 0.269 & 265612 \\
Brideprice & 0.221 & 0.415 & 249919 \\
Endogamy & 0.248 & 0.432 & 264000 \\
Stem family & 0.973 & 0.161 & 262236 \\
Polygyny & 0.846 & 0.36 & 264917 \\
Virilocality & 0.984 & 0.126 & 259283 \\
Sedentary & 0.016 & 0.126 & 259283 \\
Nomadic & 0.548 & 0.498 & 259283 \\
Compact & 0.154 & 0.361 & 259283 \\
Isolated & 0.046 & 0.209 & 244914 \\
Gender equal land inheritance & 0.142 & 0.349 & 244914 \\
Matrilineal land inheritance & 0.629 & 0.483 & 232667 \\
Primogeniture land inheritance & 0 & \\
\hline \hline
\end{tabular}

Notes: Source: Murdock's Ethnographic Atlas and Demographic and Health Survey (DHS). Survey weights are always included. All DHS African countries with data on women's attitudes towards domestic violence are considered. Overall there are 28 countries in the sample. 
Table 4: Contemporaneous correlates

\begin{tabular}{|c|c|c|c|c|c|c|}
\hline & \multicolumn{4}{|c|}{ Women } & \multicolumn{2}{|c|}{ Men } \\
\hline & $\begin{array}{c}(1) \\
\text { violence } \\
\text { ever }\end{array}$ & $\begin{array}{c}(2) \\
\text { violence } \\
\text { index }\end{array}$ & $\begin{array}{c}(3) \\
\text { attitude } \\
\text { dummy }\end{array}$ & $\begin{array}{c}(4) \\
\text { attitude } \\
\text { index }\end{array}$ & $\begin{array}{c}(5) \\
\text { attitude } \\
\text { dummy }\end{array}$ & $\begin{array}{c}(6) \\
\text { attitude } \\
\text { index }\end{array}$ \\
\hline Age & $\begin{array}{c}-0.002^{* *} \\
(0.001)\end{array}$ & $\begin{array}{c}-0.003 \\
(0.002)\end{array}$ & $\begin{array}{c}-0.004^{* * *} \\
(0.001)\end{array}$ & $\begin{array}{c}-0.015^{* * *} \\
(0.002)\end{array}$ & $\begin{array}{c}-0.004^{* * *} \\
(0.001)\end{array}$ & $\begin{array}{c}-0.009 * * * \\
(0.002)\end{array}$ \\
\hline Education (years) & $\begin{array}{c}-0.001 \\
(0.001)\end{array}$ & $\begin{array}{l}-0.003 \\
(0.003)\end{array}$ & $\begin{array}{c}-0.011^{* * *} \\
(0.001)\end{array}$ & $\begin{array}{c}-0.039^{* * *} \\
(0.004)\end{array}$ & $\begin{array}{c}-0.008^{* * *} \\
(0.001)\end{array}$ & $\begin{array}{c}-0.025^{* * *} \\
(0.004)\end{array}$ \\
\hline Wealth index & $\begin{array}{l}-0.001 \\
(0.001)\end{array}$ & $\begin{array}{c}-0.004 \\
(0.003)\end{array}$ & $\begin{array}{l}-0.002 \\
(0.002)\end{array}$ & $\begin{array}{c}-0.018^{* *} \\
(0.008)\end{array}$ & $\begin{array}{c}-0.005^{* * *} \\
(0.002)\end{array}$ & $\begin{array}{c}-0.020 * * * \\
(0.005)\end{array}$ \\
\hline Working & $\begin{array}{c}0.043^{* * *} \\
(0.010)\end{array}$ & $\begin{array}{c}0.117^{* * * *} \\
(0.026)\end{array}$ & $\begin{array}{l}-0.005 \\
(0.009)\end{array}$ & $\begin{array}{l}-0.038 \\
(0.033)\end{array}$ & $\begin{array}{l}-0.014 \\
(0.016)\end{array}$ & $\begin{array}{l}-0.035 \\
(0.062)\end{array}$ \\
\hline Number of births & $\begin{array}{c}0.012^{* * *} \\
(0.003)\end{array}$ & $\begin{array}{c}0.031^{* * *} \\
(0.008)\end{array}$ & $\begin{array}{c}0.007^{* * * *} \\
(0.001)\end{array}$ & $\begin{array}{c}0.030^{* * *} \\
(0.006)\end{array}$ & $\begin{array}{c}0.005^{* * *} \\
(0.001)\end{array}$ & $\begin{array}{c}0.011^{* * *} \\
(0.004)\end{array}$ \\
\hline Household size & $\begin{array}{c}0.002^{* *} \\
(0.001)\end{array}$ & $\begin{array}{c}0.003 \\
(0.002)\end{array}$ & $\begin{array}{c}0.002^{* *} \\
(0.001)\end{array}$ & $\begin{array}{c}0.006 \\
(0.004)\end{array}$ & $\begin{array}{c}0.001 \\
(0.001)\end{array}$ & $\begin{array}{c}0.003 \\
(0.003)\end{array}$ \\
\hline Partner's age & $\begin{array}{c}-0.002^{* * *} \\
(0.000)\end{array}$ & $\begin{array}{c}-0.004^{* * *} \\
(0.001)\end{array}$ & $\begin{array}{l}-0.000 \\
(0.000)\end{array}$ & $\begin{array}{c}0.002 \\
(0.001)\end{array}$ & $\begin{array}{c}-0.002^{* * *} \\
(0.001)\end{array}$ & $\begin{array}{c}-0.005^{* * *} \\
(0.002)\end{array}$ \\
\hline Partner's education & $\begin{array}{l}-0.001 \\
(0.001)\end{array}$ & $\begin{array}{c}-0.005^{*} \\
(0.003)\end{array}$ & $\begin{array}{c}-0.003^{* * *} \\
(0.001)\end{array}$ & $\begin{array}{c}-0.010^{* * *} \\
(0.002)\end{array}$ & $\begin{array}{c}-0.005^{* * *} \\
(0.001)\end{array}$ & $\begin{array}{c}-0.013^{* * *} \\
(0.002)\end{array}$ \\
\hline Urban & $\begin{array}{c}0.037^{* * *} \\
(0.010)\end{array}$ & $\begin{array}{c}0.086^{* * *} \\
(0.029)\end{array}$ & $\begin{array}{c}-0.061^{* * *} \\
(0.011)\end{array}$ & $\begin{array}{c}-0.289^{* * *} \\
(0.045)\end{array}$ & $\begin{array}{c}-0.027^{* * *} \\
(0.008)\end{array}$ & $\begin{array}{c}-0.123^{* * *} \\
(0.028)\end{array}$ \\
\hline Constant & $\begin{array}{c}0.123^{* * *} \\
(0.028)\end{array}$ & $\begin{array}{c}0.216^{* * * *} \\
(0.063)\end{array}$ & $\begin{array}{c}0.281^{* * * *} \\
(0.026)\end{array}$ & $\begin{array}{c}0.845^{* * *} \\
(0.102)\end{array}$ & $\begin{array}{c}0.231^{* *} \\
(0.095)\end{array}$ & $\begin{array}{c}-0.057 \\
(0.428)\end{array}$ \\
\hline Observations & 68,224 & 68,119 & 156,869 & 152,374 & 49,351 & 48,483 \\
\hline R-squared & 0.119 & 0.100 & 0.226 & 0.245 & 0.150 & 0.136 \\
\hline Mean dep. var & 0.272 & 0.578 & 0.479 & 1.413 & 0.313 & 0.721 \\
\hline
\end{tabular}

Notes: OLS estimates. Standard errors in parenthesis clustered at the ethnicity level. ***, $* *$ and $*$ indicate significance at $1 \%, 5 \%$ and $10 \%$ levels, respectively. Column headings indicate the dependent variable considered. The bottom line reports the mean of the dependent variable. Coefficients and standard errors of the variable Wealth index are multiplied by 100000 . Controls include country fixed effects and religion dummies. Sample coverage: for actual violence (cols. 1-2) all 18 African countries with domestic violence module are included; for violence attitudes (cols. 3-6) there are 28 African countries for the female sample and 27 for the male one. 
Table 5: Cultural correlates - economic value of women

\begin{tabular}{|c|c|c|c|c|c|c|}
\hline & \multicolumn{4}{|c|}{ Women } & \multicolumn{2}{|c|}{ Men } \\
\hline & $\begin{array}{c}(1) \\
\text { violence } \\
\text { ever }\end{array}$ & $\begin{array}{c}(2) \\
\text { violence } \\
\text { index }\end{array}$ & $\begin{array}{c}(3) \\
\text { attitude } \\
\text { dummy }\end{array}$ & $\begin{array}{c}(4) \\
\text { attitude } \\
\text { index }\end{array}$ & $\begin{array}{c}(5) \\
\text { attitude } \\
\text { dummy }\end{array}$ & $\begin{array}{c}(6) \\
\text { attitude } \\
\text { index }\end{array}$ \\
\hline A. Brideprice & $\begin{array}{c}-0.115^{* *} \\
(0.049)\end{array}$ & $\begin{array}{c}-0.354^{* * *} \\
(0.130)\end{array}$ & $\begin{array}{c}-0.008 \\
(0.029)\end{array}$ & $\begin{array}{l}-0.009 \\
(0.105)\end{array}$ & $\begin{array}{c}-0.061^{* * *} \\
(0.020)\end{array}$ & $\begin{array}{l}-0.147^{*} \\
(0.075)\end{array}$ \\
\hline Observations & 67,996 & 67,892 & 156,391 & 151,909 & 49,210 & 48,343 \\
\hline R-squared & 0.122 & 0.104 & 0.226 & 0.245 & 0.152 & 0.137 \\
\hline Mean dep. var & 0.271 & 0.576 & 0.478 & 1.410 & 0.312 & 0.720 \\
\hline B. Plough & $\begin{array}{c}0.132^{* * * *} \\
(0.035)\end{array}$ & $\begin{array}{c}0.344^{* *} \\
(0.146)\end{array}$ & $\begin{array}{c}0.006 \\
(0.050)\end{array}$ & $\begin{array}{c}-0.274 \\
(0.254)\end{array}$ & $\begin{array}{c}-0.023 \\
(0.087)\end{array}$ & $\begin{array}{r}-0.295 \\
(0.334)\end{array}$ \\
\hline Observations & 66,030 & 65,926 & 153,111 & 148,728 & 48,307 & 47,448 \\
\hline R-squared & 0.123 & 0.102 & 0.226 & 0.243 & 0.152 & 0.137 \\
\hline Mean dep. var & 0.270 & 0.576 & 0.483 & 1.426 & 0.314 & 0.725 \\
\hline C. Agriculture main source & $\begin{array}{l}-0.037 \\
(0.035)\end{array}$ & $\begin{array}{l}-0.007 \\
(0.091)\end{array}$ & $\begin{array}{l}-0.030 \\
(0.025)\end{array}$ & $\begin{array}{c}-0.183^{*} \\
(0.100)\end{array}$ & $\begin{array}{l}-0.022 \\
(0.035)\end{array}$ & $\begin{array}{r}-0.117 \\
(0.095)\end{array}$ \\
\hline Observations & 68,224 & 68,119 & 156,869 & 152,374 & 49,351 & 48,483 \\
\hline R-squared & 0.119 & 0.100 & 0.226 & 0.245 & 0.150 & 0.136 \\
\hline Mean dep. var & 0.272 & 0.578 & 0.479 & 1.413 & 0.313 & 0.721 \\
\hline D. Dependence on agriculture & $\begin{array}{c}-0.068 \\
(0.068)\end{array}$ & $\begin{array}{c}-0.116 \\
(0.189)\end{array}$ & $\begin{array}{c}0.056 \\
(0.059)\end{array}$ & $\begin{array}{c}0.053 \\
(0.205)\end{array}$ & $\begin{array}{c}0.049 \\
(0.055)\end{array}$ & $\begin{array}{c}0.078 \\
(0.154)\end{array}$ \\
\hline Observations & 68,224 & 68,119 & 156,869 & 152,374 & 49,351 & 48,483 \\
\hline R-squared & 0.119 & 0.100 & 0.226 & 0.245 & 0.151 & 0.136 \\
\hline Mean dep. var & 0.272 & 0.578 & 0.479 & 1.413 & 0.313 & 0.721 \\
\hline E. Dependence on gathering & $\begin{array}{c}-0.346^{*} \\
(0.195)\end{array}$ & $\begin{array}{c}-0.957^{* *} \\
(0.479)\end{array}$ & $\begin{array}{l}-0.082 \\
(0.167)\end{array}$ & $\begin{array}{c}-0.012 \\
(0.653)\end{array}$ & $\begin{array}{l}-0.120 \\
(0.177)\end{array}$ & $\begin{array}{c}0.110 \\
(0.506)\end{array}$ \\
\hline Observations & 68,224 & 68,119 & 156,869 & 152,374 & 49,351 & 48,483 \\
\hline R-squared & 0.120 & 0.100 & 0.226 & 0.245 & 0.151 & 0.136 \\
\hline Mean dep. var & 0.272 & 0.578 & 0.479 & 1.413 & 0.313 & 0.721 \\
\hline F. Dependence on hunting & $\begin{array}{c}0.319 \\
(0.242)\end{array}$ & $\begin{array}{c}0.773 \\
(0.686)\end{array}$ & $\begin{array}{c}0.292^{* *} \\
(0.143)\end{array}$ & $\begin{array}{c}0.782 \\
(0.576)\end{array}$ & $\begin{array}{c}0.051 \\
(0.196)\end{array}$ & $\begin{array}{c}0.209 \\
(0.535)\end{array}$ \\
\hline Observations & 68,224 & 68,119 & 156,869 & 152,374 & 49,351 & 48,483 \\
\hline R-squared & 0.119 & 0.100 & 0.226 & 0.245 & 0.150 & 0.136 \\
\hline Mean dep. var & 0.272 & 0.578 & 0.479 & 1.413 & 0.313 & 0.721 \\
\hline G. Dependence on fishing & $\begin{array}{c}0.227 * * \\
(0.093)\end{array}$ & $\begin{array}{c}0.536^{* *} \\
(0.248)\end{array}$ & $\begin{array}{l}-0.135 \\
(0.099)\end{array}$ & $\begin{array}{l}-0.416 \\
(0.360)\end{array}$ & $\begin{array}{c}0.047 \\
(0.075)\end{array}$ & $\begin{array}{r}-0.029 \\
(0.213)\end{array}$ \\
\hline Observations & 68,224 & 68,119 & 156,869 & 152,374 & 49,351 & 48,483 \\
\hline R-squared & 0.120 & 0.100 & 0.226 & 0.245 & 0.150 & 0.136 \\
\hline Mean dep. var & 0.272 & 0.578 & 0.479 & 1.413 & 0.313 & 0.721 \\
\hline
\end{tabular}


Table 5: Cultural correlates - economic value of women (CONTINUED)

\begin{tabular}{|c|c|c|c|c|c|c|}
\hline & \multicolumn{4}{|c|}{ Women } & \multicolumn{2}{|c|}{ Men } \\
\hline & $\begin{array}{c}(1) \\
\text { violence } \\
\text { ever }\end{array}$ & $\begin{array}{c}(2) \\
\text { violence } \\
\text { index }\end{array}$ & $\begin{array}{c}(3) \\
\text { attitude } \\
\text { dummy }\end{array}$ & $\begin{array}{c}(4) \\
\text { attitude } \\
\text { index }\end{array}$ & $\begin{array}{c}\text { (5) } \\
\text { attitude } \\
\text { dummy }\end{array}$ & $\begin{array}{c}(6) \\
\text { attitude } \\
\text { index }\end{array}$ \\
\hline H. Dependence on husbandry & $\begin{array}{c}-0.041 \\
(0.086)\end{array}$ & $\begin{array}{l}-0.147 \\
(0.218)\end{array}$ & $\begin{array}{l}-0.038 \\
(0.062)\end{array}$ & $\begin{array}{c}0.056 \\
(0.248)\end{array}$ & $\begin{array}{c}-0.084 \\
(0.063)\end{array}$ & $\begin{array}{r}-0.158 \\
(0.183)\end{array}$ \\
\hline Observations & 68,224 & 68,119 & 156,869 & 152,374 & 49,351 & 48,483 \\
\hline R-squared & 0.119 & 0.100 & 0.226 & 0.245 & 0.151 & 0.136 \\
\hline Mean dep. var & 0.272 & 0.578 & 0.479 & 1.413 & 0.313 & 0.721 \\
\hline I. Plough-positive crops & $\begin{array}{c}0.022 \\
(0.060)\end{array}$ & $\begin{array}{c}0.057 \\
(0.153)\end{array}$ & $\begin{array}{c}0.184^{* * *} * \\
(0.064)\end{array}$ & $\begin{array}{c}0.796^{* * *} \\
(0.250)\end{array}$ & $\begin{array}{c}0.079 \\
(0.071)\end{array}$ & $\begin{array}{c}0.273 \\
(0.214)\end{array}$ \\
\hline Plough-negative crops & $\begin{array}{c}0.052 \\
(0.094)\end{array}$ & $\begin{array}{c}0.113 \\
(0.258)\end{array}$ & $\begin{array}{c}0.068 \\
(0.042)\end{array}$ & $\begin{array}{c}0.397 * * \\
(0.166)\end{array}$ & $\begin{array}{l}-0.004 \\
(0.055)\end{array}$ & $\begin{array}{c}0.065 \\
(0.152)\end{array}$ \\
\hline Observations & 66,288 & 66,193 & 153,080 & 148,872 & 48,117 & 47,290 \\
\hline R-squared & 0.118 & 0.099 & 0.229 & 0.248 & 0.151 & 0.137 \\
\hline Mean dep. var & 0.268 & 0.568 & 0.479 & 1.420 & 0.313 & 0.724 \\
\hline Equality of coefficients (p-value) & 0.800 & 0.867 & 0.075 & 0.057 & 0.352 & 0.403 \\
\hline
\end{tabular}

Notes: OLS estimates. Standard errors in parenthesis clustered at the ethnicity level. $* * *, * *$ and $*$ indicate significance at $1 \%, 5 \%$ and $10 \%$ levels, respectively. Column headings indicate the dependent variable considered. The bottom line reports the mean of the dependent variable. Controls include: age, education (years), wealth index, working dummy, number of births, household size, partner's age and education, urban status, religion dummies and country fixed effects. Sample coverage: for actual violence (cols. 1-2) all 18 African countries with domestic violence module are included; for violence attitudes (cols. 3-6) there are 28 African countries for the female sample and 27 for the male one. 
Table 6: Cultural correlates - marriage patterns

\begin{tabular}{|c|c|c|c|c|c|c|}
\hline & \multicolumn{4}{|c|}{ Women } & \multicolumn{2}{|c|}{ Men } \\
\hline & $\begin{array}{c}(1) \\
\text { violence } \\
\text { ever }\end{array}$ & $\begin{array}{c}(2) \\
\text { violence } \\
\text { index }\end{array}$ & $\begin{array}{c}(3) \\
\text { attitude } \\
\text { dummy }\end{array}$ & $\begin{array}{c}(4) \\
\text { attitude } \\
\text { index }\end{array}$ & $\begin{array}{c}(5) \\
\text { attitude } \\
\text { dummy }\end{array}$ & $\begin{array}{c}(6) \\
\text { attitude } \\
\text { index }\end{array}$ \\
\hline A. Endogamy & $\begin{array}{c}0.069^{* * *} \\
(0.023)\end{array}$ & $\begin{array}{c}0.188^{* * *} \\
(0.066)\end{array}$ & $\begin{array}{c}-0.014 \\
(0.019)\end{array}$ & $\begin{array}{c}0.004 \\
(0.087)\end{array}$ & $\begin{array}{l}0.033^{*} \\
(0.019)\end{array}$ & $\begin{array}{c}0.113^{*} \\
(0.062)\end{array}$ \\
\hline Observations & 64,313 & 64,223 & 147,292 & 142,932 & 46,072 & 45,231 \\
\hline R-squared & 0.120 & 0.101 & 0.234 & 0.251 & 0.157 & 0.141 \\
\hline Mean dep. var & 0.266 & 0.562 & 0.478 & 1.419 & 0.311 & 0.719 \\
\hline B. Stem family & $\begin{array}{l}-0.022 \\
(0.020)\end{array}$ & $\begin{array}{l}-0.061 \\
(0.049)\end{array}$ & $\begin{array}{c}-0.035^{*} \\
(0.020)\end{array}$ & $\begin{array}{c}-0.160^{* *} \\
(0.078)\end{array}$ & $\begin{array}{c}-0.011 \\
(0.017)\end{array}$ & $\begin{array}{l}-0.074^{*} \\
(0.041)\end{array}$ \\
\hline Observations & 68,054 & 67,949 & 155,899 & 152,070 & 49,090 & 48,388 \\
\hline R-squared & 0.119 & 0.100 & 0.223 & 0.246 & 0.146 & 0.136 \\
\hline Mean dep. var & 0.272 & 0.577 & 0.478 & 1.416 & 0.311 & 0.722 \\
\hline C. Polygyny & $\begin{array}{l}-0.009 \\
(0.015)\end{array}$ & $\begin{array}{l}-0.059 \\
(0.053)\end{array}$ & $\begin{array}{c}-0.006 \\
(0.025)\end{array}$ & $\begin{array}{c}0.051 \\
(0.196)\end{array}$ & $\begin{array}{c}0.037 \\
(0.055)\end{array}$ & $\begin{array}{c}0.259 \\
(0.196)\end{array}$ \\
\hline Observations & 67,710 & 67,605 & 154,966 & 151,153 & 48,433 & 47,737 \\
\hline R-squared & 0.119 & 0.100 & 0.224 & 0.246 & 0.148 & 0.138 \\
\hline Mean dep. var & 0.272 & 0.578 & 0.477 & 1.416 & 0.311 & 0.724 \\
\hline D. Virilocality & $\begin{array}{c}0.010 \\
(0.018)\end{array}$ & $\begin{array}{c}0.054 \\
(0.056)\end{array}$ & $\begin{array}{c}0.006 \\
(0.027)\end{array}$ & $\begin{array}{c}0.079 \\
(0.099)\end{array}$ & $\begin{array}{l}-0.016 \\
(0.022)\end{array}$ & $\begin{array}{r}-0.003 \\
(0.064)\end{array}$ \\
\hline Observations & 67,856 & 67,751 & 156,167 & 151,690 & 48,853 & 47,991 \\
\hline R-squared & 0.119 & 0.100 & 0.226 & 0.245 & 0.152 & 0.138 \\
\hline Mean dep. var & 0.272 & 0.578 & 0.479 & 1.412 & 0.313 & 0.722 \\
\hline
\end{tabular}

Notes: OLS estimates. Standard errors in parenthesis clustered at the ethnicity level. $* * *, * *$ and $*$ indicate significance at $1 \%, 5 \%$ and $10 \%$ levels, respectively. Column headings indicate the dependent variable considered. The bottom line reports the mean of the dependent variable. Controls include: age, education (years), wealth index, working dummy, number of births, household size, partner's age and education, urban status, religion dummies and country fixed effects. Sample coverage: for actual violence (cols. 1-2) all 18 African countries with domestic violence module are included; for violence attitudes (cols. 3-6) there are 28 African countries for the female sample and 27 for the male one. 
Table 7: Cultural correlates - types of settlements

\begin{tabular}{|c|c|c|c|c|c|c|}
\hline & \multicolumn{4}{|c|}{ Women } & \multicolumn{2}{|c|}{ Men } \\
\hline & $\begin{array}{c}(1) \\
\text { violence } \\
\text { ever }\end{array}$ & $\begin{array}{c}(2) \\
\text { violence } \\
\text { index }\end{array}$ & $\begin{array}{c}(3) \\
\text { attitude } \\
\text { dummy }\end{array}$ & $\begin{array}{c}(4) \\
\text { attitude } \\
\text { index }\end{array}$ & $\begin{array}{c}(5) \\
\text { attitude } \\
\text { dummy }\end{array}$ & $\begin{array}{c}(6) \\
\text { attitude } \\
\text { index }\end{array}$ \\
\hline \multicolumn{7}{|c|}{ Settlements types } \\
\hline Nomadic & $\begin{array}{c}0.077^{*} \\
(0.043)\end{array}$ & $\begin{array}{c}0.068 \\
(0.113)\end{array}$ & $\begin{array}{l}-0.018 \\
(0.031)\end{array}$ & $\begin{array}{c}0.030 \\
(0.128)\end{array}$ & $\begin{array}{l}-0.017 \\
(0.033)\end{array}$ & $\begin{array}{c}0.037 \\
(0.100)\end{array}$ \\
\hline Isolated & $\begin{array}{c}0.046 \\
(0.035)\end{array}$ & $\begin{array}{c}0.127 \\
(0.096)\end{array}$ & $\begin{array}{c}0.059^{*} \\
(0.032)\end{array}$ & $\begin{array}{c}0.281^{* *} \\
(0.137)\end{array}$ & $\begin{array}{l}-0.026 \\
(0.031)\end{array}$ & $\begin{array}{c}0.006 \\
(0.102)\end{array}$ \\
\hline Compact & $\begin{array}{c}0.000 \\
(0.017)\end{array}$ & $\begin{array}{l}-0.001 \\
(0.041)\end{array}$ & $\begin{array}{l}-0.020 \\
(0.027)\end{array}$ & $\begin{array}{l}-0.038 \\
(0.094)\end{array}$ & $\begin{array}{c}-0.048^{* * *} \\
(0.014)\end{array}$ & $\begin{array}{c}-0.114^{* *} \\
(0.049)\end{array}$ \\
\hline Observations & 65,850 & 65,746 & 152,904 & 148,521 & 48,251 & 47,393 \\
\hline R-squared & 0.123 & 0.103 & 0.227 & 0.244 & 0.153 & 0.137 \\
\hline Mean dep. var & 0.270 & 0.577 & 0.483 & 1.428 & 0.314 & 0.725 \\
\hline
\end{tabular}

Notes: OLS estimates. Standard errors in parenthesis clustered at the ethnicity level. $* * *, * *$ and $*$ indicate significance at $1 \%, 5 \%$ and $10 \%$ levels, respectively. The omitted category is sedentary settlements. Column headings indicate the dependent variable considered. The bottom line reports the mean of the dependent variable. Controls include: age, education (years), wealth index, working dummy, number of births, household size, partner's age and education, urban status, religion dummies and country fixed effects. Sample coverage: for actual violence (cols. 1-2) all 18 African countries with domestic violence module are included; for violence attitudes (cols. 3-6) there are 28 African countries for the female sample and 27 for the male one. 
Table 8: Contemporaneous women employment - heterogenous effects

\begin{tabular}{|c|c|c|c|c|c|c|}
\hline & \multicolumn{4}{|c|}{ "Women } & \multicolumn{2}{|c|}{ Men } \\
\hline & $\begin{array}{c}(1) \\
\text { violence } \\
\text { ever }\end{array}$ & $\begin{array}{c}(2) \\
\text { violence } \\
\text { index }\end{array}$ & $\begin{array}{c}\text { (3) } \\
\text { attitude } \\
\text { dummy }\end{array}$ & $\begin{array}{c}(4) \\
\text { attitude } \\
\text { index }\end{array}$ & $\begin{array}{c}\text { (5) } \\
\text { attitude } \\
\text { dummy }\end{array}$ & $\begin{array}{c}(6) \\
\text { attitude } \\
\text { index }\end{array}$ \\
\hline A. Brideprice & $\begin{array}{l}-0.052 \\
(0.046)\end{array}$ & $\begin{array}{c}-0.202^{*} \\
(0.110)\end{array}$ & $\begin{array}{c}0.015 \\
(0.032)\end{array}$ & $\begin{array}{c}0.122 \\
(0.088)\end{array}$ & $\begin{array}{c}-0.037 \\
(0.039)\end{array}$ & $\begin{array}{l}-0.061 \\
(0.103)\end{array}$ \\
\hline Working & $\begin{array}{c}0.138^{* * *} \\
(0.030)\end{array}$ & $\begin{array}{c}0.344^{* * *} * \\
(0.052)\end{array}$ & $\begin{array}{c}0.031 \\
(0.031)\end{array}$ & $\begin{array}{c}0.164 \\
(0.121)\end{array}$ & $\begin{array}{c}0.008 \\
(0.047)\end{array}$ & $\begin{array}{c}0.044 \\
(0.135)\end{array}$ \\
\hline Working*brideprice & $\begin{array}{c}-0.100^{* * *} \\
(0.032)\end{array}$ & $\begin{array}{c}-0.238^{* * *} \\
(0.059)\end{array}$ & $\begin{array}{l}-0.040 \\
(0.032)\end{array}$ & $\begin{array}{c}-0.222^{*} \\
(0.126)\end{array}$ & $\begin{array}{l}-0.026 \\
(0.050)\end{array}$ & $\begin{array}{r}-0.093 \\
(0.150)\end{array}$ \\
\hline Test (p-value) & 0.000 & 0.000 & 0.319 & 0.087 & 0.299 & 0.482 \\
\hline Observations & 67,996 & 67,892 & 156,391 & 151,909 & 49,210 & 48,343 \\
\hline R-squared & 0.122 & 0.104 & 0.226 & 0.245 & 0.152 & 0.137 \\
\hline Mean dep. var & 0.271 & 0.576 & 0.478 & 1.410 & 0.312 & 0.720 \\
\hline B. Plough & $\begin{array}{c}0.203^{* * *} * \\
(0.057)\end{array}$ & $\begin{array}{c}0.529 * * * \\
(0.179)\end{array}$ & $\begin{array}{c}0.021 \\
(0.053)\end{array}$ & $\begin{array}{l}-0.277 \\
(0.259)\end{array}$ & $\begin{array}{c}-0.036 \\
(0.083)\end{array}$ & $\begin{array}{c}-0.326 \\
(0.318)\end{array}$ \\
\hline Working & $\begin{array}{c}0.042^{* * *} * \\
(0.010)\end{array}$ & $\begin{array}{c}0.119 * * * \\
(0.027)\end{array}$ & $\begin{array}{l}-0.002 \\
(0.009)\end{array}$ & $\begin{array}{l}-0.033 \\
(0.036)\end{array}$ & $\begin{array}{c}-0.018 \\
(0.018)\end{array}$ & $\begin{array}{l}-0.045 \\
(0.076)\end{array}$ \\
\hline Working*plough & $\begin{array}{c}-0.097^{* *} \\
(0.042)\end{array}$ & $\begin{array}{c}-0.252^{* *} \\
(0.101)\end{array}$ & $\begin{array}{c}-0.028^{* *} \\
(0.014)\end{array}$ & $\begin{array}{c}0.007 \\
(0.048)\end{array}$ & $\begin{array}{c}0.015 \\
(0.036)\end{array}$ & $\begin{array}{c}0.036 \\
(0.109)\end{array}$ \\
\hline Test (p-value) & 0.187 & 0.171 & 0.004 & 0.460 & 0.905 & 0.905 \\
\hline Observations & 66,030 & 65,926 & 153,111 & 148,728 & 48,307 & 47,448 \\
\hline R-squared & 0.123 & 0.102 & 0.226 & 0.243 & 0.152 & 0.137 \\
\hline Mean dep. var & 0.270 & 0.576 & 0.483 & 1.426 & 0.314 & 0.725 \\
\hline C. Agriculture main source & $\begin{array}{l}-0.034 \\
(0.043)\end{array}$ & $\begin{array}{c}0.036 \\
(0.093)\end{array}$ & $\begin{array}{l}-0.029 \\
(0.020)\end{array}$ & $\begin{array}{c}-0.210^{* *} \\
(0.086)\end{array}$ & $\begin{array}{c}-0.017 \\
(0.044)\end{array}$ & $\begin{array}{l}-0.010 \\
(0.121)\end{array}$ \\
\hline Working & $\begin{array}{c}0.050 \\
(0.044)\end{array}$ & $\begin{array}{c}0.204^{* *} \\
(0.103)\end{array}$ & $\begin{array}{l}-0.004 \\
(0.029)\end{array}$ & $\begin{array}{c}-0.105 \\
(0.093)\end{array}$ & $\begin{array}{c}-0.009 \\
(0.029)\end{array}$ & $\begin{array}{c}0.082 \\
(0.058)\end{array}$ \\
\hline Working*agriculture main source & $\begin{array}{l}-0.007 \\
(0.045)\end{array}$ & $\begin{array}{l}-0.088 \\
(0.104)\end{array}$ & $\begin{array}{l}-0.001 \\
(0.030)\end{array}$ & $\begin{array}{c}0.070 \\
(0.099)\end{array}$ & $\begin{array}{c}-0.006 \\
(0.033)\end{array}$ & $\begin{array}{r}-0.122 \\
(0.086)\end{array}$ \\
\hline Test (p-value) & 0.000 & 0.000 & 0.568 & 0.314 & 0.390 & 0.535 \\
\hline Observations & 68,224 & 68,119 & 156,869 & 152,374 & 49,351 & 48,483 \\
\hline R-squared & 0.119 & 0.100 & 0.226 & 0.245 & 0.150 & 60.136 \\
\hline Mean dep. var & 0.272 & 0.578 & 0.479 & 1.413 & 0.313 & 0.721 \\
\hline D. Dependence on agriculture & $\begin{array}{l}-0.084 \\
(0.071)\end{array}$ & $\begin{array}{l}-0.130 \\
(0.196)\end{array}$ & $\begin{array}{c}0.034 \\
(0.054)\end{array}$ & $\begin{array}{l}-0.088 \\
(0.208)\end{array}$ & $\begin{array}{c}0.122 \\
(0.100)\end{array}$ & $\begin{array}{c}0.568 \\
(0.396)\end{array}$ \\
\hline Working & $\begin{array}{c}0.029 \\
(0.038)\end{array}$ & $\begin{array}{c}0.106 \\
(0.097)\end{array}$ & $\begin{array}{l}-0.027 \\
(0.038)\end{array}$ & $\begin{array}{l}-0.175 \\
(0.126)\end{array}$ & $\begin{array}{c}0.030 \\
(0.054)\end{array}$ & $\begin{array}{c}0.266 \\
(0.186)\end{array}$ \\
\hline Working*dependence on agriculture & $\begin{array}{c}0.023 \\
(0.060)\end{array}$ & $\begin{array}{c}0.020 \\
(0.157)\end{array}$ & $\begin{array}{c}0.035 \\
(0.064)\end{array}$ & $\begin{array}{c}0.223 \\
(0.210)\end{array}$ & $\begin{array}{l}-0.078 \\
(0.102)\end{array}$ & $\begin{array}{r}-0.527 \\
(0.399)\end{array}$ \\
\hline Test (p-value) & 0.046 & 0.071 & 0.790 & 0.615 & 0.357 & 0.236 \\
\hline Observations & 68,224 & 68,119 & 156,869 & 152,374 & 49,351 & 48,483 \\
\hline R-squared & 0.119 & 0.100 & 0.226 & 0.245 & 0.151 & 0.136 \\
\hline Mean dep. var & 0.272 & 0.578 & 0.479 & 1.413 & 0.313 & 0.721 \\
\hline
\end{tabular}


Table 8: Contemporaneous women employment - heterogenous effects (CONTINUED)

\begin{tabular}{|c|c|c|c|c|c|c|}
\hline & \multicolumn{4}{|c|}{ Women } & \multicolumn{2}{|c|}{ Men } \\
\hline & $\begin{array}{c}(1) \\
\text { violence } \\
\text { ever }\end{array}$ & $\begin{array}{c}(2) \\
\text { violence } \\
\text { index }\end{array}$ & $\begin{array}{c}\text { (3) } \\
\text { attitude } \\
\text { dummy }\end{array}$ & $\begin{array}{c}(4) \\
\text { attitude } \\
\text { index }\end{array}$ & $\begin{array}{c}(5) \\
\text { attitude } \\
\text { dummy }\end{array}$ & $\begin{array}{c}(6) \\
\text { attitude } \\
\text { index }\end{array}$ \\
\hline E. Dependence on gathering & $\begin{array}{c}-0.052 \\
(0.178)\end{array}$ & $\begin{array}{c}-0.228 \\
(0.441)\end{array}$ & $\begin{array}{c}-0.030 \\
(0.188)\end{array}$ & $\begin{array}{c}0.257 \\
(0.720)\end{array}$ & $\begin{array}{c}-0.096 \\
(0.336)\end{array}$ & $\begin{array}{c}0.492 \\
(1.112)\end{array}$ \\
\hline Working & $\begin{array}{c}0.073^{* * *} \\
(0.014)\end{array}$ & $\begin{array}{c}0.192^{* * *} \\
(0.034)\end{array}$ & $\begin{array}{c}0.000 \\
(0.009)\end{array}$ & $\begin{array}{c}-0.011 \\
(0.040)\end{array}$ & $\begin{array}{l}-0.013 \\
(0.027)\end{array}$ & $\begin{array}{l}-0.007 \\
(0.063)\end{array}$ \\
\hline Working*dependence on gathering & $\begin{array}{c}-0.423^{* *} \\
(0.169)\end{array}$ & $\begin{array}{c}-1.050^{* *} \\
(0.439)\end{array}$ & $\begin{array}{l}-0.080 \\
(0.141)\end{array}$ & $\begin{array}{l}-0.408 \\
(0.600)\end{array}$ & $\begin{array}{l}-0.025 \\
(0.360)\end{array}$ & $\begin{array}{r}-0.400 \\
(1.227)\end{array}$ \\
\hline Test (p-value) & 0.029 & 0.039 & 0.557 & 0.466 & 0.911 & 0.731 \\
\hline Observations & 68,224 & 68,119 & 156,869 & 152,374 & 49,351 & 48,483 \\
\hline R-squared & 0.120 & 0.101 & 0.226 & 0.245 & 0.151 & 0.136 \\
\hline Mean dep. var & 0.272 & 0.578 & 0.479 & 1.413 & 0.313 & 0.721 \\
\hline F. Dependence on hunting & $\begin{array}{c}0.323 \\
(0.239)\end{array}$ & $\begin{array}{c}0.712 \\
(0.672)\end{array}$ & $\begin{array}{l}0.298^{*} \\
(0.167)\end{array}$ & $\begin{array}{c}0.616 \\
(0.609)\end{array}$ & $\begin{array}{c}-0.330 \\
(0.263)\end{array}$ & $\begin{array}{l}-1.206 \\
(0.943)\end{array}$ \\
\hline Working & $\begin{array}{c}0.043^{* *} \\
(0.020)\end{array}$ & $\begin{array}{c}0.109^{* *} \\
(0.053)\end{array}$ & $\begin{array}{c}-0.005 \\
(0.018)\end{array}$ & $\begin{array}{c}-0.061 \\
(0.058)\end{array}$ & $\begin{array}{c}-0.052^{*} \\
(0.030)\end{array}$ & $\begin{array}{l}-0.175 \\
(0.130)\end{array}$ \\
\hline Working*dependence on hunting & $\begin{array}{l}-0.006 \\
(0.167)\end{array}$ & $\begin{array}{c}0.086 \\
(0.440)\end{array}$ & $\begin{array}{l}-0.009 \\
(0.152)\end{array}$ & $\begin{array}{c}0.238 \\
(0.486)\end{array}$ & $\begin{array}{c}0.403 \\
(0.300)\end{array}$ & $\begin{array}{c}1.496 \\
(0.938)\end{array}$ \\
\hline Test (p-value) & 0.804 & 0.621 & 0.919 & 0.687 & 0.204 & 0.107 \\
\hline Observations & 68,224 & 68,119 & 156,869 & 152,374 & 49,351 & 48,483 \\
\hline R-squared & 0.119 & 0.100 & 0.226 & 0.245 & 0.151 & 0.136 \\
\hline Mean dep. var & 0.272 & 0.578 & 0.479 & 1.413 & 0.313 & 0.721 \\
\hline G. Dependence on fishing & $\begin{array}{c}0.212^{* *} \\
(0.106)\end{array}$ & $\begin{array}{c}0.611^{* *} \\
(0.291)\end{array}$ & $\begin{array}{c}-0.178 \\
(0.118)\end{array}$ & $\begin{array}{l}-0.536 \\
(0.465)\end{array}$ & $\begin{array}{l}-0.085 \\
(0.206)\end{array}$ & $\begin{array}{l}-0.962 \\
(0.851)\end{array}$ \\
\hline Working & $\begin{array}{c}0.041^{* *} \\
(0.016)\end{array}$ & $\begin{array}{c}0.124^{* *} \\
(0.049)\end{array}$ & $\begin{array}{c}-0.010 \\
(0.014)\end{array}$ & $\begin{array}{c}-0.052 \\
(0.054)\end{array}$ & $\begin{array}{c}-0.027 \\
(0.032)\end{array}$ & $\begin{array}{c}-0.120 \\
(0.137)\end{array}$ \\
\hline Working*dependence on fishing & $\begin{array}{c}0.021 \\
(0.121)\end{array}$ & $\begin{array}{l}-0.104 \\
(0.341)\end{array}$ & $\begin{array}{c}0.062 \\
(0.105)\end{array}$ & $\begin{array}{c}0.175 \\
(0.429)\end{array}$ & $\begin{array}{c}0.139 \\
(0.230)\end{array}$ & $\begin{array}{c}0.980 \\
(0.956)\end{array}$ \\
\hline Test (p-value) & 0.569 & 0.947 & 0.582 & 0.752 & 0.576 & 0.298 \\
\hline Observations & 68,224 & 68,119 & 156,869 & 152,374 & 49,351 & 48,483 \\
\hline R-squared & 0.120 & 0.100 & 0.226 & 0.245 & 0.150 & 0.136 \\
\hline Mean dep. var & 0.272 & 0.578 & 0.479 & 1.413 & 0.313 & 0.721 \\
\hline H. Dependence on husbandry & $\begin{array}{l}-0.056 \\
(0.075)\end{array}$ & $\begin{array}{l}-0.236 \\
(0.183)\end{array}$ & $\begin{array}{l}-0.016 \\
(0.054)\end{array}$ & $\begin{array}{c}0.180 \\
(0.231)\end{array}$ & $\begin{array}{l}-0.024 \\
(0.079)\end{array}$ & $\begin{array}{l}-0.085 \\
(0.223)\end{array}$ \\
\hline Working & $\begin{array}{c}0.038^{* *} \\
(0.015)\end{array}$ & $\begin{array}{c}0.085^{* *} \\
(0.037)\end{array}$ & $\begin{array}{c}0.004 \\
(0.014)\end{array}$ & $\begin{array}{c}0.014 \\
(0.054)\end{array}$ & $\begin{array}{c}0.000 \\
(0.022)\end{array}$ & $\begin{array}{l}-0.018 \\
(0.083)\end{array}$ \\
\hline Working*dependence on husbandry & $\begin{array}{c}0.028 \\
(0.079)\end{array}$ & $\begin{array}{c}0.172 \\
(0.214)\end{array}$ & $\begin{array}{l}-0.048 \\
(0.052)\end{array}$ & $\begin{array}{l}-0.269 \\
(0.191)\end{array}$ & $\begin{array}{l}-0.068 \\
(0.062)\end{array}$ & $\begin{array}{r}-0.082 \\
(0.201)\end{array}$ \\
\hline Test (p-value) & 0.341 & 0.174 & 0.295 & 0.093 & 0.175 & 0.526 \\
\hline Observations & 68,224 & 68,119 & 156,869 & 152,374 & 49,351 & 48,483 \\
\hline R-squared & 0.119 & 0.100 & 0.226 & 0.245 & 0.151 & 0.136 \\
\hline Mean dep. var & 0.272 & 0.578 & 0.479 & 1.413 & 0.313 & 0.721 \\
\hline
\end{tabular}


Table 8: Contemporaneous women employment - heterogenous effects (CONTINUED)

\begin{tabular}{|c|c|c|c|c|c|c|}
\hline & \multicolumn{4}{|c|}{ Women } & \multicolumn{2}{|c|}{ Men } \\
\hline & $\begin{array}{c}(1) \\
\text { violence } \\
\text { ever } \\
\end{array}$ & $\begin{array}{c}(2) \\
\text { violence } \\
\text { index } \\
\end{array}$ & $\begin{array}{c}(3) \\
\text { attitude } \\
\text { dummy }\end{array}$ & $\begin{array}{c}(4) \\
\text { attitude } \\
\text { index }\end{array}$ & $\begin{array}{c}(5) \\
\text { attitude } \\
\text { dummy }\end{array}$ & $\begin{array}{c}(6) \\
\text { attitude } \\
\text { index }\end{array}$ \\
\hline I. Endogamy & $\begin{array}{c}0.054^{* * *} \\
(0.020)\end{array}$ & $\begin{array}{c}0.156^{* * *} \\
(0.056)\end{array}$ & $\begin{array}{c}-0.027 \\
(0.020)\end{array}$ & $\begin{array}{c}-0.061 \\
(0.091)\end{array}$ & $\begin{array}{c}0.003 \\
(0.029)\end{array}$ & $\begin{array}{c}0.032 \\
(0.098)\end{array}$ \\
\hline Working & $\begin{array}{c}0.035^{* * *} \\
(0.010)\end{array}$ & $\begin{array}{c}0.099^{* * *} \\
(0.029)\end{array}$ & $\begin{array}{l}-0.010 \\
(0.010)\end{array}$ & $\begin{array}{l}-0.061 \\
(0.037)\end{array}$ & $\begin{array}{l}-0.026 \\
(0.022)\end{array}$ & $\begin{array}{l}-0.066 \\
(0.089)\end{array}$ \\
\hline Working*endogamy & $\begin{array}{c}0.023 \\
(0.016)\end{array}$ & $\begin{array}{c}0.049 \\
(0.049)\end{array}$ & $\begin{array}{c}0.022 \\
(0.016)\end{array}$ & $\begin{array}{c}0.104 \\
(0.069)\end{array}$ & $\begin{array}{c}0.032 \\
(0.028)\end{array}$ & $\begin{array}{c}0.088 \\
(0.095)\end{array}$ \\
\hline Test (p-value) & 0.000 & 0.000 & 0.365 & 0.480 & 0.719 & 0.570 \\
\hline Observations & 64,313 & 64,223 & 147,292 & 142,932 & 46,072 & 45,231 \\
\hline R-squared & 0.120 & 0.102 & 0.234 & 0.251 & 0.157 & 0.141 \\
\hline Mean dep. var & 0.266 & 0.562 & 0.478 & 1.419 & 0.311 & 0.719 \\
\hline J. Stem family & $\begin{array}{c}-0.013 \\
(0.017)\end{array}$ & $\begin{array}{c}-0.024 \\
(0.046)\end{array}$ & $\begin{array}{c}-0.023 \\
(0.023)\end{array}$ & $\begin{array}{c}-0.137 \\
(0.088)\end{array}$ & $\begin{array}{c}0.056 \\
(0.038)\end{array}$ & $\begin{array}{c}0.243 \\
(0.183)\end{array}$ \\
\hline Working & $\begin{array}{c}0.046^{* * *} \\
(0.010)\end{array}$ & $\begin{array}{c}0.131^{* * *} \\
(0.027)\end{array}$ & $\begin{array}{c}-0.001 \\
(0.009)\end{array}$ & $\begin{array}{c}-0.033 \\
(0.039)\end{array}$ & $\begin{array}{l}-0.001 \\
(0.015)\end{array}$ & $\begin{array}{c}0.029 \\
(0.037)\end{array}$ \\
\hline Working*stem family & $\begin{array}{l}-0.013 \\
(0.022)\end{array}$ & $\begin{array}{l}-0.055 \\
(0.055)\end{array}$ & $\begin{array}{l}-0.019 \\
(0.021)\end{array}$ & $\begin{array}{l}-0.038 \\
(0.077)\end{array}$ & $\begin{array}{c}-0.071^{*} \\
(0.042)\end{array}$ & $\begin{array}{l}-0.333^{*} \\
(0.195)\end{array}$ \\
\hline Test (p-value) & 0.0810 & 0.1016 & 0.2961 & 0.2807 & 0.0693 & 0.1152 \\
\hline Observations & 68,054 & 67,949 & 155,899 & 152,070 & 49,090 & 48,388 \\
\hline R-squared & 0.119 & 0.100 & 0.224 & 0.246 & 0.146 & 0.137 \\
\hline Mean dep. var & 0.272 & 0.577 & 0.478 & 1.416 & 0.311 & 0.722 \\
\hline K. Polygyny & $\begin{array}{l}-0.022 \\
(0.015)\end{array}$ & $\begin{array}{c}-0.072 \\
(0.045)\end{array}$ & $\begin{array}{c}-0.017 \\
(0.027)\end{array}$ & $\begin{array}{c}0.051 \\
(0.192)\end{array}$ & $\begin{array}{l}-0.014 \\
(0.058)\end{array}$ & $\begin{array}{c}0.128 \\
(0.209)\end{array}$ \\
\hline Working & $\begin{array}{c}0.014 \\
(0.013)\end{array}$ & $\begin{array}{c}0.086^{* *} \\
(0.041)\end{array}$ & $\begin{array}{c}-0.035^{* * *} \\
(0.006)\end{array}$ & $\begin{array}{c}-0.036 \\
(0.024)\end{array}$ & $\begin{array}{c}-0.066^{* * *} \\
(0.006)\end{array}$ & $\begin{array}{c}-0.172^{* * *} \\
(0.015)\end{array}$ \\
\hline Working*polygyny & $\begin{array}{c}0.030^{* *} \\
(0.015)\end{array}$ & $\begin{array}{c}0.031 \\
(0.046)\end{array}$ & $\begin{array}{c}0.031^{* * *} \\
(0.010)\end{array}$ & $\begin{array}{l}-0.002 \\
(0.040)\end{array}$ & $\begin{array}{c}0.058^{* * *} \\
(0.018)\end{array}$ & $\begin{array}{l}0.152^{* *} \\
(0.068)\end{array}$ \\
\hline Test (p-value) & 0.000 & 0.000 & 0.634 & 0.263 & 0.638 & 0.767 \\
\hline Observations & 67,710 & 67,605 & 154,966 & 151,153 & 48,433 & 47,737 \\
\hline R-squared & 0.119 & 0.100 & 0.224 & 0.246 & 0.148 & 0.138 \\
\hline Mean dep. var & 0.272 & 0.578 & 0.477 & 1.416 & 0.311 & 0.724 \\
\hline L. Virilocality & $\begin{array}{c}0.018 \\
(0.020)\end{array}$ & $\begin{array}{c}0.046 \\
(0.052)\end{array}$ & $\begin{array}{c}0.011 \\
(0.029)\end{array}$ & $\begin{array}{c}0.096 \\
(0.102)\end{array}$ & $\begin{array}{l}-0.015 \\
(0.028)\end{array}$ & $\begin{array}{c}-0.006 \\
(0.100)\end{array}$ \\
\hline Working & $\begin{array}{c}0.053^{* * *} \\
(0.018)\end{array}$ & $\begin{array}{c}0.106^{* * *} \\
(0.034)\end{array}$ & $\begin{array}{c}0.001 \\
(0.016)\end{array}$ & $\begin{array}{l}-0.015 \\
(0.060)\end{array}$ & $\begin{array}{l}-0.013 \\
(0.026)\end{array}$ & $\begin{array}{l}-0.038 \\
(0.078)\end{array}$ \\
\hline Working*Virilocality & $\begin{array}{l}-0.012 \\
(0.021)\end{array}$ & $\begin{array}{c}0.013 \\
(0.046)\end{array}$ & $\begin{array}{c}-0.007 \\
(0.019)\end{array}$ & $\begin{array}{l}-0.027 \\
(0.074)\end{array}$ & $\begin{array}{l}-0.002 \\
(0.031)\end{array}$ & $\begin{array}{c}0.004 \\
(0.104)\end{array}$ \\
\hline Test (p-value) & 0.001 & 0.002 & 0.518 & 0.260 & 0.432 & 0.625 \\
\hline Observations & 67,856 & 67,751 & 156,167 & 151,690 & 48,853 & 47,991 \\
\hline R-squared & 0.119 & 0.100 & 0.226 & 0.245 & 0.152 & 0.138 \\
\hline Mean dep. var & 0.272 & 0.578 & 0.479 & 1.412 & 0.313 & 0.722 \\
\hline
\end{tabular}

Notes: OLS estimates. Standard errors in parenthesis clustered at the ethnicity level. ***, ** and $*$ indicate significance at $1 \%, 5 \%$ and $10 \%$ levels, respectively. Column headings indicate the dependent variable considered. The bottom line reports the mean of the dependent variable. The p-value of the test that sum of the coefficients of the variable Working and the interaction term is equal to 0 is also reported. Controls include: age, education (years), wealth index, working dummy, number of births, household size, partner's age and education, urban status, religion dummies and country fixed effects. Sample coverage: for actual violence (cols. 1-2) all 18 African countries with domestic violence module are included; for violence attitudes (cols. 3-6) there are 28 African countries for the female sample and 27 for the male one. 


\section{Appendix}

\subsection{Additional tables}

Table A.1: Variables used in the analysis and their sources

\begin{tabular}{lc}
\hline \hline Variable & Source \\
\hline Dependent variables & \\
\hline Violence ever & DHS \\
Violence index ever & DHS \\
Violence attitude dummy (women) & DHS \\
Violence attitude index (women) & DHS \\
Violence attitude dummy (men) & DHS \\
Violence attitude index (men) & DHS \\
\hline Ethnographic variables & \\
\hline Plough & Ethnographic Atlas \\
Agriculture main source & Ethnographic Atlas \\
Dependence on agriculture & Ethnographic Atlas \\
Dependence on gathering & Ethnographic Atlas \\
Dependence on hunting & Ethnographic Atlas \\
Dependence on fishing & Ethnographic Atlas \\
Dependence on husbandry & Ethnographic Atlas \\
Brideprice & Ethnographic Atlas \\
Endogamy & Ethnographic Atlas \\
Stem family & Ethnographic Atlas \\
Polygyny & Ethnographic Atlas \\
Virilocality & Ethnographic Atlas \\
Nomadic & Ethnographic Atlas \\
Isolated & Ethnographic Atlas \\
Compact & Ethnographic Atlas \\
Gender equal land inheritance & Ethnographic Atlas \\
Matrilineal land inheritance & Ethnographic Atlas \\
Primogeniture land inheritance & Ethnographic Atlas \\
\hline Contemporary controls & \\
\hline Age & DHS \\
Education & DHS \\
Wealth index & DHS \\
Working & DHS \\
Number of births & DHS \\
Household size & DHS \\
Partner's age & DHS \\
Partner's education & DHS \\
Urban & DHS \\
Religion & DHS \\
Country FE & DHS \\
\hline \hline & \\
\hline
\end{tabular}

Notes: A detailed description of how dependent and independent variables have been constructed is provided in Section A2 and Section A3 of the Appendix, respectively. 
Table A.2: Summary statistics

\begin{tabular}{lccc}
\hline \hline & Mean & Std. Dev. & $\mathrm{N}$ \\
\hline Ethnographic variables & & & \\
\hline Plough & 0.002 & 0.042 & 92835 \\
Agriculture main source & 0.986 & 0.116 & 96077 \\
Dependence on agriculture & 0.638 & 0.13 & 96077 \\
Dependence on gathering & 0.065 & 0.048 & 96077 \\
Dependence on hunting & 0.089 & 0.059 & 96077 \\
Dependence on fishing & 0.086 & 0.073 & 96077 \\
Dependence on husbandry & 0.177 & 0.1 & 96077 \\
Female participation agriculture & 0.704 & 0.456 & 82467 \\
Female participation gathering & 0.903 & 0.297 & 42992 \\
Female participation hunting & 0 & 0 & 61663 \\
Female participation fishing & 0.16 & 0.367 & 50771 \\
Female participation husbandry & 0.398 & 0.489 & 59416 \\
Brideprice & 0.947 & 0.224 & 95769 \\
Endogamy & 0.197 & 0.398 & 90290 \\
Stem family & 0.27 & 0.444 & 95788 \\
Polygyny & 0.994 & 0.075 & 95275 \\
Virilocality & 0.843 & 0.364 & 95538 \\
Sedentary & 0.989 & 0.105 & 92553 \\
Nomadic & 0.011 & 0.105 & 92553 \\
Compact & 0.531 & 0.499 & 92553 \\
Isolated & 0.189 & 0.391 & 92553 \\
Gender equal land inheritance & 0.042 & 0.201 & 87962 \\
Matrilineal land inheritance & 0.139 & 0.346 & 87962 \\
Primogeniture land inheritance & 0.638 & 0.481 & 84386 \\
\hline \hline
\end{tabular}

Notes: Source: Murdock's Ethnographic Atlas and Demographic and Health Survey (DHS). Countries with the violence module are considered. The sample is composed by women selected and interviewed for domestic violence module. Overall, 18 African countries are considered. 
Table A.3: Summary statistics (controls)

\begin{tabular}{|c|c|c|c|c|c|c|}
\hline & \multicolumn{3}{|c|}{ Women } & \multicolumn{3}{|c|}{ Men } \\
\hline & Mean & Std. Dev. & $\mathrm{N}$ & Mean & Std. Dev. & $\mathrm{N}$ \\
\hline \multicolumn{7}{|c|}{ Attitudes towards violence } \\
\hline Age & 28.438 & 9.425 & 266361 & 30.397 & 11.625 & 120099 \\
\hline Education (years) & 4.873 & 4.632 & 266242 & 6.62 & 4.776 & 120014 \\
\hline Wealth index & 0.183 & 2.074 & 266361 & 0.23 & 2.063 & 120099 \\
\hline Working & 0.575 & 0.494 & 265785 & 0.776 & 0.417 & 119900 \\
\hline Number of births & 2.857 & 2.767 & 266361 & 2.55 & 3.552 & 119932 \\
\hline Household size & 6.885 & 4.302 & 266361 & 6.307 & 4.147 & 120099 \\
\hline Partner's age & 39.731 & 11.616 & 174184 & 30.424 & 8.081 & 51291 \\
\hline Partner's education & 5.327 & 5.221 & 191533 & 4.275 & 4.512 & 51272 \\
\hline Urban & 0.384 & 0.486 & 266361 & 0.402 & 0.49 & 120099 \\
\hline \multicolumn{7}{|c|}{ Actual violence experienced } \\
\hline Age & 29.095 & 9.075 & 96077 & - & - & - \\
\hline Education (years) & 5.208 & 4.75 & 96033 & - & - & - \\
\hline Wealth index & 0.057 & 1.87 & 96077 & - & - & - \\
\hline Working & 0.629 & 0.483 & 95840 & - & - & - \\
\hline Number of births & 3.011 & 2.662 & 96077 & - & - & - \\
\hline Household size & 5.569 & 2.921 & 96077 & - & - & - \\
\hline Partner's age & 38.927 & 11.21 & 69873 & - & - & - \\
\hline Partner's education & 5.939 & 5.245 & 76080 & - & - & - \\
\hline Urban & 0.367 & 0.482 & 96077 & - & - & - \\
\hline
\end{tabular}

Notes: Source: Murdock's Ethnographic Atlas and Demographic and Health Survey (DHS). Descriptive statistics for the variable Wealth index have been obtained by dividing the wealth index factor score by 100000. Survey weights are always included. Sample coverage: for violence attitudes there are 28 African countries for the female sample and 27 for the male one; for actual violence all 18 African countries with domestic violence module are included. 
Table A.4: Cultural correlates - economic value of women (Probit \& Poisson estimates)

\begin{tabular}{|c|c|c|c|c|c|c|}
\hline & \multicolumn{4}{|c|}{ Women } & \multicolumn{2}{|c|}{ Men } \\
\hline & $\begin{array}{c}(1) \\
\text { violence } \\
\text { ever }\end{array}$ & $\begin{array}{c}(2) \\
\text { violence } \\
\text { index }\end{array}$ & $\begin{array}{c}(3) \\
\text { attitude } \\
\text { dummy }\end{array}$ & $\begin{array}{c}(4) \\
\text { attitude } \\
\text { index }\end{array}$ & $\begin{array}{c}(5) \\
\text { attitude } \\
\text { dummy }\end{array}$ & $\begin{array}{c}\text { (6) } \\
\text { attitude } \\
\text { index }\end{array}$ \\
\hline A. Brideprice & $\begin{array}{c}-0.099^{* *} \\
(0.038)\end{array}$ & $\begin{array}{c}0.637^{* * *} \\
(0.098)\end{array}$ & $\begin{array}{l}-0.008 \\
(0.031)\end{array}$ & $\begin{array}{c}0.993 \\
(0.078)\end{array}$ & $\begin{array}{c}-0.059^{* * *} \\
(0.020)\end{array}$ & $\begin{array}{c}0.841^{*} \\
(0.083)\end{array}$ \\
\hline Observations & 67,996 & 67,892 & 153,849 & 151,909 & 48,636 & 48,343 \\
\hline Pseudo R-squared & 0.110 & & 0.170 & & 0.108 & \\
\hline Mean dep. var. & 0.271 & 0.576 & 0.470 & 1.410 & 0.304 & 0.720 \\
\hline B. Plough & $\begin{array}{c}0.097^{* * *} \\
(0.025)\end{array}$ & $\begin{array}{l}1.214^{*} \\
(0.131)\end{array}$ & $\begin{array}{c}0.006 \\
(0.048)\end{array}$ & $\begin{array}{c}0.868 \\
(0.092)\end{array}$ & $\begin{array}{l}-0.014 \\
(0.066)\end{array}$ & $\begin{array}{c}0.813 \\
(0.180)\end{array}$ \\
\hline Observations & 66,030 & 65,926 & 150,569 & 148,728 & 47,733 & 47,448 \\
\hline Pseudo R-squared & 0.111 & & 0.170 & & 0.109 & \\
\hline Mean dep. var. & 0.270 & 0.576 & 0.474 & 1.410 & 0.305 & 0.725 \\
\hline C. Agriculture main source & $\begin{array}{l}-0.045 \\
(0.031)\end{array}$ & $\begin{array}{c}0.914 \\
(0.139)\end{array}$ & $\begin{array}{l}-0.027 \\
(0.023)\end{array}$ & $\begin{array}{c}0.941 \\
(0.047)\end{array}$ & $\begin{array}{c}-0.023 \\
(0.032)\end{array}$ & $\begin{array}{c}0.883 \\
(0.096)\end{array}$ \\
\hline Observations & 68,224 & 68,119 & 154,327 & 152,374 & 48,777 & 48,483 \\
\hline Pseudo R-squared & 0.107 & & 0.170 & & 0.107 & \\
\hline Mean dep. var. & 0.272 & 0.578 & 0.470 & 1.413 & 0.305 & 0.721 \\
\hline D. Dependence on agriculture & $\begin{array}{c}-0.066 \\
(0.066)\end{array}$ & $\begin{array}{c}0.769 \\
(0.265)\end{array}$ & $\begin{array}{c}0.069 \\
(0.061)\end{array}$ & $\begin{array}{c}1.088 \\
(0.170)\end{array}$ & $\begin{array}{c}0.052 \\
(0.055)\end{array}$ & $\begin{array}{c}1.112 \\
(0.217)\end{array}$ \\
\hline Observations & 68,224 & 68,119 & 154,327 & 152,374 & 48,777 & 48,483 \\
\hline Pseudo R-squared & 0.107 & & 0.170 & & 0.107 & \\
\hline Mean dep. var. & 0.272 & 0.578 & 0.470 & 1.413 & 0.305 & 0.721 \\
\hline E. Dependence on gathering & $\begin{array}{c}-0.367^{*} \\
(0.204)\end{array}$ & $\begin{array}{l}0.146^{*} \\
(0.144)\end{array}$ & $\begin{array}{l}-0.105 \\
(0.173)\end{array}$ & $\begin{array}{c}1.070 \\
(0.451)\end{array}$ & $\begin{array}{c}-0.114 \\
(0.173)\end{array}$ & $\begin{array}{c}1.275 \\
(0.784)\end{array}$ \\
\hline Observations & 68,224 & 68,119 & 154,327 & 152,374 & 48,777 & 48,483 \\
\hline Pseudo R-squared & 0.108 & & 0.170 & & 0.107 & \\
\hline Mean dep. var. & 0.272 & 0.578 & 0.470 & 1.413 & 0.305 & 0.721 \\
\hline F. Dependence on hunting & $\begin{array}{c}0.301 \\
(0.239)\end{array}$ & $\begin{array}{c}3.552 \\
(4.595)\end{array}$ & $\begin{array}{c}0.338^{* *} \\
(0.151)\end{array}$ & $\begin{array}{c}2.115 \\
(1.188)\end{array}$ & $\begin{array}{c}0.040 \\
(0.213)\end{array}$ & $\begin{array}{c}1.298 \\
(1.165)\end{array}$ \\
\hline Observations & 68,224 & 68,119 & 154,327 & 152,374 & 48,777 & 48,483 \\
\hline Pseudo R-squared & 0.108 & & 0.170 & & 0.107 & \\
\hline Mean dep. var. & 0.272 & 0.578 & 0.470 & 1.413 & 0.305 & 0.721 \\
\hline G. Dependence on fishing & $\begin{array}{c}0.240^{* * * *} \\
(0.091)\end{array}$ & $\begin{array}{c}3.011^{* *} \\
(1.350)\end{array}$ & $\begin{array}{l}-0.135 \\
(0.100)\end{array}$ & $\begin{array}{c}0.754 \\
(0.196)\end{array}$ & $\begin{array}{c}0.042 \\
(0.077)\end{array}$ & $\begin{array}{c}0.936 \\
(0.277)\end{array}$ \\
\hline Observations & 68,224 & 68,119 & 154,327 & 152,374 & 48,777 & 48,483 \\
\hline Pseudo R-squared & 0.108 & & 0.170 & & 0.107 & \\
\hline Mean dep. var. & 0.272 & 0.578 & 0.470 & 1.413 & 0.305 & 0.721 \\
\hline
\end{tabular}


Table A.4: Cultural correlates - economic value of women (Probit \& Poisson estimates) - CONTINUED

\begin{tabular}{|c|c|c|c|c|c|c|}
\hline & \multicolumn{4}{|c|}{ Women } & \multicolumn{2}{|c|}{ Men } \\
\hline & $\begin{array}{c}(1) \\
\text { violence } \\
\text { ever }\end{array}$ & $\begin{array}{l}(2) \\
\text { violence } \\
\text { index }\end{array}$ & $\begin{array}{c}\text { (3) } \\
\text { attitude } \\
\text { dummy }\end{array}$ & $\begin{array}{l}(4) \\
\text { attitude } \\
\text { index }\end{array}$ & $\begin{array}{l}(5) \\
\text { attitude } \\
\text { dummy }\end{array}$ & $\begin{array}{l}(6) \\
\text { attitude } \\
\text { index }\end{array}$ \\
\hline H. Dependence on husbandry & $\begin{array}{c}-0.044 \\
(0.084)\end{array}$ & $\begin{array}{c}0.769 \\
(0.332)\end{array}$ & $\begin{array}{l}-0.055 \\
(0.060)\end{array}$ & $\begin{array}{c}0.947 \\
(0.139)\end{array}$ & $\begin{array}{c}-0.076 \\
(0.057)\end{array}$ & $\begin{array}{c}0.829 \\
(0.170)\end{array}$ \\
\hline $\begin{array}{l}\text { Observations } \\
\text { Pseudo R-squared } \\
\text { Mean dep. var. }\end{array}$ & $\begin{array}{c}68,224 \\
0.107 \\
0.272\end{array}$ & $\begin{array}{r}68,119 \\
0.578\end{array}$ & $\begin{array}{c}154,327 \\
0.170 \\
0.470\end{array}$ & $\begin{array}{c}152,374 \\
1.413\end{array}$ & $\begin{array}{c}48,777 \\
0.108 \\
0.305\end{array}$ & $\begin{array}{r}48,483 \\
0.721\end{array}$ \\
\hline $\begin{array}{l}\text { I. Plough-positive crops } \\
\text { Plough-negative crops }\end{array}$ & $\begin{array}{c}0.006 \\
(0.048) \\
0.032 \\
(0.077)\end{array}$ & $\begin{array}{c}0.996 \\
(0.201) \\
1.143 \\
(0.380)\end{array}$ & $\begin{array}{c}0.201^{* * *} \\
(0.072) \\
0.084 \\
(0.052)\end{array}$ & $\begin{array}{c}1.973^{* * *} \\
(0.400) \\
1.346^{* * *} \\
(0.148)\end{array}$ & $\begin{array}{c}0.081 \\
(0.067) \\
-0.012 \\
(0.061)\end{array}$ & $\begin{array}{c}1.477 \\
(0.393) \\
1.086 \\
(0.250)\end{array}$ \\
\hline $\begin{array}{l}\text { Observations } \\
\text { Pseudo R-squared } \\
\text { Mean dep. var. } \\
\text { Equality of coefficients (p-value) }\end{array}$ & $\begin{array}{c}66,288 \\
0.107 \\
0.268 \\
0.769\end{array}$ & $\begin{array}{l}0.568 \\
0.719\end{array}$ & $\begin{array}{c}150,755 \\
0.172 \\
0.471 \\
0.111\end{array}$ & $\begin{array}{l}1.420 \\
0.044\end{array}$ & $\begin{array}{l}47,552 \\
0.108 \\
0.305 \\
0.314\end{array}$ & $\begin{array}{l}0.724 \\
0.402\end{array}$ \\
\hline
\end{tabular}

Notes: Columns (1), (3) and (5) report probit estimates (marginal effects reported), while columns (2), (4) and (6) report poisson estimates (incidence-rate ratios reported, meaning that coefficients are exponentiated). Standard errors in parenthesis clustered at the ethnicity level. ${ }^{* * *}, * *$ and $*$ indicate significance at $1 \%, 5 \%$ and $10 \%$ levels, respectively. Column headings indicate the dependent variable considered. The bottom line reports the mean of the dependent variable. Controls include: age, education (years), wealth index, working dummy, number of births, household size, partner's age and education, urban status, religion dummies and country fixed effects. Sample coverage: for actual violence (cols. 1-2) all 18 African countries with domestic violence module are included; for violence attitudes (cols. 3-6) there are 28 African countries for the female sample and 27 for the male one. 
Table A.5: Cultural correlates - marriage patterns (Probit \& Poisson)

\begin{tabular}{|c|c|c|c|c|c|c|}
\hline & \multicolumn{4}{|c|}{ Women } & \multicolumn{2}{|c|}{ Men } \\
\hline & $\begin{array}{c}(1) \\
\text { violence } \\
\text { ever }\end{array}$ & $\begin{array}{c}(2) \\
\text { violence } \\
\text { index }\end{array}$ & $\begin{array}{c}(3) \\
\text { attitude } \\
\text { dummy }\end{array}$ & $\begin{array}{c}(4) \\
\text { attitude } \\
\text { index }\end{array}$ & $\begin{array}{c}(5) \\
\text { attitude } \\
\text { dummy }\end{array}$ & $\begin{array}{c}(6) \\
\text { attitude } \\
\text { index }\end{array}$ \\
\hline A. Endogamy & $\begin{array}{c}0.059 * * * \\
(0.021)\end{array}$ & $\begin{array}{c}1.298^{* * *} \\
(0.122)\end{array}$ & $\begin{array}{l}-0.014 \\
(0.018)\end{array}$ & $\begin{array}{c}0.996 \\
(0.052)\end{array}$ & $\begin{array}{l}0.032^{*} \\
(0.018)\end{array}$ & $\begin{array}{c}1.141^{*} \\
(0.084)\end{array}$ \\
\hline Observations & 64,313 & 64,223 & 144,750 & 142,932 & 45,498 & 45,231 \\
\hline Pseudo R-squared & 0.108 & & 0.175 & & 0.112 & \\
\hline Mean dep. var. & 0.266 & 0.562 & 0.469 & 1.413 & 0.303 & 0.719 \\
\hline B. Stem family & $\begin{array}{c}-0.031 \\
(0.027)\end{array}$ & $\begin{array}{c}0.844 \\
(0.134)\end{array}$ & $\begin{array}{c}-0.034^{*} \\
(0.018)\end{array}$ & $\begin{array}{l}0.906^{*} \\
(0.051)\end{array}$ & $\begin{array}{l}-0.009 \\
(0.016)\end{array}$ & $\begin{array}{c}0.923 \\
(0.061)\end{array}$ \\
\hline Observations & 68,054 & 67,949 & 154,022 & 152,070 & 48,682 & 48,388 \\
\hline Pseudo R-squared & 0.108 & & 0.170 & & 0.107 & \\
\hline Mean dep. var. & 0.272 & 0.577 & 0.471 & 1.416 & 0.305 & 0.722 \\
\hline C. Polygyny & $\begin{array}{l}-0.004 \\
(0.014)\end{array}$ & $\begin{array}{c}0.911 \\
(0.074)\end{array}$ & $\begin{array}{c}0.003 \\
(0.028)\end{array}$ & $\begin{array}{c}1.105 \\
(0.093)\end{array}$ & $\begin{array}{c}0.031 \\
(0.045)\end{array}$ & $\begin{array}{c}1.256 \\
(0.180)\end{array}$ \\
\hline Observations & 67,710 & 67,605 & 153,089 & 151,153 & 48,025 & 47,737 \\
\hline $\begin{array}{l}\text { Pseudo R-squared } \\
\text { Mean dep. var. }\end{array}$ & $\begin{array}{l}0.107 \\
0.272 \\
\end{array}$ & 0.578 & $\begin{array}{l}0.170 \\
0.471 \\
\end{array}$ & 1.416 & $\begin{array}{l}0.109 \\
0.306 \\
\end{array}$ & 0.724 \\
\hline D. Virilocality & $\begin{array}{c}0.008 \\
(0.016)\end{array}$ & $\begin{array}{c}1.094 \\
(0.092)\end{array}$ & $\begin{array}{c}0.005 \\
(0.032)\end{array}$ & $\begin{array}{c}0.973 \\
(0.097)\end{array}$ & $\begin{array}{l}-0.022 \\
(0.025)\end{array}$ & $\begin{array}{c}0.939 \\
(0.091)\end{array}$ \\
\hline Observations & 67,856 & 67,751 & 153,625 & 151,690 & 48,279 & 47,991 \\
\hline Pseudo R-squared & 0.107 & & 0.170 & & 0.109 & \\
\hline Mean dep. var. & 0.272 & 0.578 & 0.470 & 1.412 & 0.305 & 0.722 \\
\hline
\end{tabular}

Notes: Columns (1), (3) and (5) report probit estimates (marginal effects reported), while columns (2), (4) and (6) report poisson estimates (incidence-rate ratios reported, meaning that coefficients are exponentiated). Standard errors in parenthesis clustered at the ethnicity level. ${ }^{* * *},{ }^{* *}$ and $*$ indicate significance at $1 \%, 5 \%$ and $10 \%$ levels, respectively. Column headings indicate the dependent variable considered. The bottom line reports the mean of the dependent variable. Controls include: age, education (years), wealth index, working dummy, number of births, household size, partner's age and education, urban status, religion dummies and country fixed effects. Sample coverage: for actual violence (cols. 1-2) all 18 African countries with domestic violence module are included; for violence attitudes (cols. 3-6) there are 28 African countries for the female sample and 27 for the male one. 
Table A.6: Cultural correlates - types of settlements (Probit \& Poisson estimates)

\begin{tabular}{|c|c|c|c|c|c|c|}
\hline & \multicolumn{4}{|c|}{ Women } & \multicolumn{2}{|c|}{ Men } \\
\hline & $\begin{array}{c}(1) \\
\text { violence } \\
\text { ever }\end{array}$ & $\begin{array}{c}(2) \\
\text { violence } \\
\text { index }\end{array}$ & $\begin{array}{c}\text { (3) } \\
\text { attitude } \\
\text { dummy }\end{array}$ & $\begin{array}{c}(4) \\
\text { attitude } \\
\text { index }\end{array}$ & $\begin{array}{c}(5) \\
\text { attitude } \\
\text { dummy }\end{array}$ & $\begin{array}{c}(6) \\
\text { attitude } \\
\text { index }\end{array}$ \\
\hline \multicolumn{7}{|l|}{ Settlements types } \\
\hline Nomadic & $\begin{array}{c}0.083^{* *} \\
(0.035)\end{array}$ & $\begin{array}{c}1.243 \\
(0.223)\end{array}$ & $\begin{array}{l}-0.021 \\
(0.030)\end{array}$ & $\begin{array}{c}0.975 \\
(0.063)\end{array}$ & $\begin{array}{l}-0.016 \\
(0.025)\end{array}$ & $\begin{array}{c}1.002 \\
(0.079)\end{array}$ \\
\hline Isolated & $\begin{array}{c}0.044 \\
(0.037)\end{array}$ & $\begin{array}{c}1.221 \\
(0.232)\end{array}$ & $\begin{array}{l}0.053^{*} \\
(0.030)\end{array}$ & $\begin{array}{l}1.176^{*} \\
(0.101)\end{array}$ & $\begin{array}{l}-0.030 \\
(0.028)\end{array}$ & $\begin{array}{c}0.945 \\
(0.114)\end{array}$ \\
\hline Compact & $\begin{array}{l}-0.008 \\
(0.022)\end{array}$ & $\begin{array}{c}0.943 \\
(0.127)\end{array}$ & $\begin{array}{l}-0.020 \\
(0.026)\end{array}$ & $\begin{array}{c}0.971 \\
(0.065)\end{array}$ & $\begin{array}{c}-0.052^{* * *} \\
(0.014)\end{array}$ & $\begin{array}{l}0.821^{* *} \\
(0.066)\end{array}$ \\
\hline Observations & 65,850 & 65,746 & 150,362 & 148,521 & 47,677 & 47,393 \\
\hline Pseudo R-squared & 0.111 & & 0.171 & & 0.109 & \\
\hline Mean dep. var. & 0.270 & 0.577 & 0.475 & 1.428 & 0.306 & 0.725 \\
\hline
\end{tabular}

Notes: Columns (1), (3) and (5) report probit estimates (marginal effects reported), while columns (2), (4) and (6) report poisson estimates (incidence-rate ratios reported, meaning that coefficients are exponentiated). Standard errors in parenthesis clustered at the ethnicity level. ${ }^{* * *},{ }^{* *}$ and $*$ indicate significance at $1 \%, 5 \%$ and $10 \%$ levels, respectively. The omitted category is sedentary settlements. Column headings indicate the dependent variable considered. The bottom line reports the mean of the dependent variable. Controls include: age, education (years), wealth index, working dummy, number of births, household size, partner's age and education, urban status, religion dummies and country fixed effects. Sample coverage: for actual violence (cols. 1-2) all 18 African countries with domestic violence module are included; for violence attitudes (cols. 3-6) there are 28 African countries for the female sample and 27 for the male one. 
Table A.7: Cultural correlates - economic value of women (restricted sample)

\begin{tabular}{|c|c|c|c|c|}
\hline & \multicolumn{2}{|c|}{ Women } & \multicolumn{2}{|c|}{ Men } \\
\hline & $\begin{array}{c}\text { (1) } \\
\text { attitude } \\
\text { dummy }\end{array}$ & $\begin{array}{c}(2) \\
\text { attitude } \\
\text { index }\end{array}$ & $\begin{array}{c}(3) \\
\text { attitude } \\
\text { dummy }\end{array}$ & $\begin{array}{c}(4) \\
\text { attitude } \\
\text { index }\end{array}$ \\
\hline A. Brideprice & $\begin{array}{c}-0.004 \\
(0.035)\end{array}$ & $\begin{array}{c}-0.031 \\
(0.134)\end{array}$ & $\begin{array}{c}-0.076^{* * *} \\
(0.022)\end{array}$ & $\begin{array}{c}-0.243^{* * *} \\
(0.071)\end{array}$ \\
\hline Observations & 118,453 & 116,914 & 37,702 & 37,467 \\
\hline R-squared & 0.178 & 0.190 & 0.110 & 0.110 \\
\hline Mean dep. var & 0.453 & 1.306 & 0.295 & 0.676 \\
\hline B. Plough & $\begin{array}{c}0.042 \\
(0.050)\end{array}$ & $\begin{array}{c}0.002 \\
(0.174)\end{array}$ & $\begin{array}{c}0.064^{* * *} \\
(0.014)\end{array}$ & $\begin{array}{c}0.056 \\
(0.041)\end{array}$ \\
\hline Observations & 115,173 & 113,733 & 36,799 & 36,572 \\
\hline R-squared & 0.178 & 0.186 & 0.110 & 0.108 \\
\hline Mean dep. var & 0.458 & 1.325 & 0.296 & 0.681 \\
\hline C. Agriculture main source & $\begin{array}{c}0.028 \\
(0.046)\end{array}$ & $\begin{array}{c}0.074 \\
(0.171)\end{array}$ & $\begin{array}{l}-0.045 \\
(0.057)\end{array}$ & $\begin{array}{r}-0.209 \\
(0.188)\end{array}$ \\
\hline Observations & 118,931 & 117,379 & 37,843 & 37,607 \\
\hline R-squared & 0.179 & 0.190 & 0.108 & 0.108 \\
\hline Mean dep. var & 0.454 & 1.311 & 0.295 & 0.677 \\
\hline D. Dependence on agriculture & $\begin{array}{c}0.095 \\
(0.073)\end{array}$ & $\begin{array}{c}0.173 \\
(0.259)\end{array}$ & $\begin{array}{c}0.031 \\
(0.069)\end{array}$ & $\begin{array}{c}0.037 \\
(0.207)\end{array}$ \\
\hline Observations & 118,931 & 117,379 & 37,843 & 37,607 \\
\hline R-squared & 0.179 & 0.190 & 0.108 & 0.108 \\
\hline Mean dep. var & 0.454 & 1.311 & 0.295 & 0.677 \\
\hline E. Dependence on gathering & $\begin{array}{c}-0.058 \\
(0.189)\end{array}$ & $\begin{array}{c}0.225 \\
(0.722)\end{array}$ & $\begin{array}{c}-0.186 \\
(0.190)\end{array}$ & $\begin{array}{r}-0.294 \\
(0.510)\end{array}$ \\
\hline Observations & 118,931 & 117,379 & 37,843 & 37,607 \\
\hline R-squared & 0.178 & 0.190 & 0.109 & 0.108 \\
\hline Mean dep. var & 0.454 & 1.311 & 0.295 & 0.677 \\
\hline F. Dependence on hunting & $\begin{array}{c}0.227 \\
(0.198)\end{array}$ & $\begin{array}{c}0.499 \\
(0.811)\end{array}$ & $\begin{array}{c}0.102 \\
(0.226)\end{array}$ & $\begin{array}{c}0.239 \\
(0.617)\end{array}$ \\
\hline Observations & 118,931 & 117,379 & 37,843 & 37,607 \\
\hline R-squared & 0.179 & 0.190 & 0.108 & 0.108 \\
\hline Mean dep. var & 0.454 & 1.311 & 0.295 & 0.677 \\
\hline G. Dependence on fishing & $\begin{array}{l}-0.135 \\
(0.110)\end{array}$ & $\begin{array}{c}-0.391 \\
(0.389)\end{array}$ & $\begin{array}{c}0.122 \\
(0.081)\end{array}$ & $\begin{array}{c}0.175 \\
(0.232)\end{array}$ \\
\hline Observations & 118,931 & 117,379 & 37,843 & 37,607 \\
\hline R-squared & 0.179 & 0.190 & 0.109 & 0.108 \\
\hline Mean dep. var & 0.454 & 1.311 & 0.295 & 0.677 \\
\hline
\end{tabular}


Table A.7: Cultural correlates - economic value of women (restricted sample) - CONT.

\begin{tabular}{|c|c|c|c|c|}
\hline & \multicolumn{2}{|c|}{ Women } & \multicolumn{2}{|c|}{ Men } \\
\hline & $\begin{array}{c}(1) \\
\text { attitude } \\
\text { dummy }\end{array}$ & $\begin{array}{c}(2) \\
\text { attitude } \\
\text { index }\end{array}$ & $\begin{array}{c}\text { (3) } \\
\text { attitude } \\
\text { dummy }\end{array}$ & $\begin{array}{c}(4) \\
\text { attitude } \\
\text { index }\end{array}$ \\
\hline H. Dependence on husbandry & $\begin{array}{l}-0.087 \\
(0.092)\end{array}$ & $\begin{array}{l}-0.090 \\
(0.358)\end{array}$ & $\begin{array}{l}-0.152 \\
(0.103)\end{array}$ & $\begin{array}{r}-0.202 \\
(0.292)\end{array}$ \\
\hline Observations & 118,931 & 117,379 & 37,843 & 37,607 \\
\hline R-squared & 0.179 & 0.190 & 0.109 & 0.108 \\
\hline Mean dep. var. & 0.454 & 1.311 & 0.295 & 0.677 \\
\hline I. Plough-positive crops & $\begin{array}{c}0.185^{* * *} \\
(0.069)\end{array}$ & $\begin{array}{c}0.767 * * * \\
(0.271)\end{array}$ & $\begin{array}{c}0.083 \\
(0.072)\end{array}$ & $\begin{array}{c}0.194 \\
(0.209)\end{array}$ \\
\hline Plough-negative crops & $\begin{array}{c}0.037 \\
(0.060)\end{array}$ & $\begin{array}{c}0.310 \\
(0.219)\end{array}$ & $\begin{array}{c}0.001 \\
(0.075)\end{array}$ & $\begin{array}{c}0.097 \\
(0.188)\end{array}$ \\
\hline Observations & 116,115 & 114,628 & 36,842 & 36,616 \\
\hline R-squared & 0.181 & 0.192 & 0.109 & 0.109 \\
\hline Mean dep. var. & 0.454 & 1.316 & 0.295 & 0.679 \\
\hline Equality of coefficients (p-value) & 0.040 & 0.014 & 0.406 & 0.654 \\
\hline
\end{tabular}

Notes: OLS estimates. Standard errors in parenthesis clustered at the ethnicity level. $* * *, * *$ and $*$ indicate significance at $1 \%, 5 \%$ and $10 \%$ levels, respectively. Column headings indicate the dependent variable considered. The bottom line reports the mean of the dependent variable. Controls include: age, education (years), wealth index, working dummy, number of births, household size, partner's age and education, urban status, religion dummies and country fixed effects. Sample coverage: in order to double check previous estimates, the sample has been restricted to only those countries for which the domestic violence module is available. 
Table A.8: Cultural correlates - marriage patterns (restricted sample)

\begin{tabular}{|c|c|c|c|c|}
\hline & \multicolumn{2}{|c|}{ Women } & \multicolumn{2}{|c|}{ Men } \\
\hline & $\begin{array}{c}\text { (1) } \\
\text { attitude } \\
\text { dummy }\end{array}$ & $\begin{array}{c}(2) \\
\text { attitude } \\
\text { index }\end{array}$ & $\begin{array}{c}(3) \\
\text { attitude } \\
\text { dummy }\end{array}$ & $\begin{array}{c}(4) \\
\text { attitude } \\
\text { index }\end{array}$ \\
\hline A. Endogamy & $\begin{array}{c}0.009 \\
(0.023)\end{array}$ & $\begin{array}{c}0.114 \\
(0.097)\end{array}$ & $\begin{array}{c}0.061^{* * *} \\
(0.018)\end{array}$ & $\begin{array}{c}0.197^{* * *} \\
(0.065)\end{array}$ \\
\hline Observations & 111,395 & 109,963 & 35,206 & 34,994 \\
\hline R-squared & 0.183 & 0.193 & 0.115 & 0.115 \\
\hline Mean dep. var & 0.451 & 1.311 & 0.291 & 0.667 \\
\hline B. Stem family & $\begin{array}{c}-0.021 \\
(0.024)\end{array}$ & $\begin{array}{l}-0.102 \\
(0.092)\end{array}$ & $\begin{array}{l}-0.007 \\
(0.017)\end{array}$ & $\begin{array}{r}-0.063 \\
(0.040)\end{array}$ \\
\hline Observations & 118,626 & 117,075 & 37,748 & 37,512 \\
\hline R-squared & 0.178 & 0.190 & 0.108 & 0.108 \\
\hline Mean dep. var & 0.455 & 1.315 & 0.296 & 0.678 \\
\hline C. Polygyny & $\begin{array}{l}-0.031 \\
(0.019)\end{array}$ & $\begin{array}{c}-0.307^{* * *} \\
(0.042)\end{array}$ & $\begin{array}{c}0.117 \\
(0.102)\end{array}$ & $\begin{array}{c}0.195 \\
(0.296)\end{array}$ \\
\hline Observations & 118,014 & 116,478 & 37,281 & 37,051 \\
\hline R-squared & 0.179 & 0.190 & 0.110 & 0.109 \\
\hline Mean dep. var & 0.455 & 1.314 & 0.296 & 0.679 \\
\hline D. Virilocality & $\begin{array}{c}0.007 \\
(0.028)\end{array}$ & $\begin{array}{c}0.074 \\
(0.099)\end{array}$ & $\begin{array}{l}-0.015 \\
(0.023)\end{array}$ & $\begin{array}{c}0.007 \\
(0.063)\end{array}$ \\
\hline Observations & 118,243 & 116,708 & 37,355 & 37,125 \\
\hline R-squared & 0.179 & 0.190 & 0.111 & 0.110 \\
\hline Mean dep. var & 0.453 & 1.310 & 0.295 & 0.678 \\
\hline
\end{tabular}

Notes: OLS estimates. Standard errors in parenthesis clustered at the ethnicity level. $* * *, * *$ and $*$ indicate significance at $1 \%, 5 \%$ and $10 \%$ levels, respectively. Column headings indicate the dependent variable considered. The bottom line reports the mean of the dependent variable. Controls include: age, education (years), wealth index, working dummy, number of births, household size, partner's age and education, urban status, religion dummies and country fixed effects. Sample coverage: in order to double check previous estimates, the sample has been restricted to only those countries for which the domestic violence module is available. 
Table A.9: Cultural correlates - types of settlements (restricted sample)

\begin{tabular}{lcccccc}
\hline \hline & \multicolumn{2}{c}{ Women } & & \multicolumn{2}{c}{ Men } \\
\cline { 2 - 3 } \cline { 5 - 6 } & $\begin{array}{c}(1) \\
\text { attitude } \\
\text { dummy }\end{array}$ & $\begin{array}{c}\text { attitude } \\
\text { index }\end{array}$ & & $\begin{array}{c}(3) \\
\text { attitude } \\
\text { dummy }\end{array}$ & $\begin{array}{c}(4) \\
\text { attitude } \\
\text { index }\end{array}$ \\
\cline { 1 - 2 } \cline { 5 - 6 } Settlements types & & & & & \\
\cline { 1 - 2 } Nomadic & -0.032 & 0.009 & & $0.112^{* * *}$ & $0.491^{* * *}$ \\
& $(0.076)$ & $(0.278)$ & & $(0.034)$ & $(0.181)$ \\
Isolated & $0.075^{*}$ & $0.343^{* *}$ & & -0.037 & -0.060 \\
& $(0.041)$ & $(0.166)$ & & $(0.035)$ & $(0.105)$ \\
Compact & -0.007 & 0.032 & & $-0.041^{* * *}$ & $-0.118^{* *}$ \\
& $(0.034)$ & $(0.112)$ & & $(0.014)$ & $(0.047)$ \\
Observations & 114,966 & 113,526 & & 36,743 & 36,517 \\
R-squared & 0.179 & 0.188 & & 0.111 & 0.110 \\
Mean dep. var & 0.459 & 1.327 & & 0.296 & 0.681 \\
\hline \hline
\end{tabular}

Notes: OLS estimates. Standard errors in parenthesis clustered at the ethnicity level. $* * *, * *$ and $*$ indicate significance at $1 \%, 5 \%$ and $10 \%$ levels, respectively. The omitted category is sedentary settlements. Column headings indicate the dependent variable considered. The bottom line reports the mean of the dependent variable. Controls include: age, education (years), wealth index, working dummy, number of births, household size, partner's age and education, urban status, religion dummies and country fixed effects. Sample coverage: in order to double check previous estimates, the sample has been restricted to only those countries for which the domestic violence module is available. 


\section{A2 Dependent variables}

The individual-level data on violence exposure are taken from the most recent wave of the Demographic and Health Surveys (DHS). The dummy called 'Violence ever', indicates whether the woman has ever been victim of at least one form of domestic violence, and the 'Violence index', is the sum of different forms of intimate partner violence to which the woman has ever been exposed. We need to restrict the attention to six different forms of aggressions common to all the countries included in the sample ${ }^{32}$. The list of violence related questions is in Appendix Table A.10.

Table A.10: Questions about domestic violence, perpetrated by spouse

\begin{tabular}{|l|l|}
\hline Types of Violence & DHS Questions \\
\hline \hline Physical Violence & (1) Ever been pushed, shook or had something thrown \\
& (2) Ever been slapped \\
& (3) Ever been punched with fist or hit by something harmful \\
& (4) Ever been kicked or dragged \\
& (5) Ever been strangled or burnt \\
\hline Sexual Violence & (6) Ever been physically forced into unwanted sexual intercourse \\
\hline
\end{tabular}

Notes: Source: DHS, Women's Questionnaire.

Concerning women's and men's attitudes towards domestic violence, we take the individual-level data on the acceptance of violence from women and men DHS datasets, respectively. These two datasets contain a set of attitudinal measures that reflect some combination of women's and men's attitudes towards both spousal violence and women. Five questions in the DHS ask respondents about the circumstances under which it would be acceptable for a man to beat his wife. These circumstances are: wife goes out without telling him; wife neglects the children; wife argues with him; wife refuses to have sex with him; wife burns the food. As our dependent variable, we use a 'Violence attitude dummy', equal to 1 if the respondent believes that violence is acceptable in at least one out of the five circumstances included in the survey. In addition, we construct a 'Violence attitude index', given by the sum of the circumstances in which the respondent thinks it would be acceptable for a man to beat his wife.

\footnotetext{
${ }^{32}$ Some questions on the occurence of specific types of either physical or sexual violence are not included in all the considered survey rounds.
} 


\section{A3 Independent variables}

\section{A3.1 Ethnographic variables}

Brideprice: it is a dummy variable, indicating whether the prevalent mode of marriage prior to industrialization was characterized by brideprice or wealth to bride's family, bride service to bride's family or token brideprice. It comes from variable v6 of the Ethnographic Atlas.

Plough: the measure is constructed from variable v39 of the Ethnographic Atlas. According to this variable, ethnicities are classified into one of the following mutual exclusive categories: (i) the plough was absent; (ii) the plough existed but it was not aboriginal; and (iii) the plough was aboriginal and found in the society prior to contact. Using this categorization, we construct an indicator variable equal to 1 if the society used the plough (without distinguishing between aboriginal or not) and 0 otherwise.

Agriculture main source: it is a dummy variable, constructed from variable v42 of the Ethnographic Atlas. Ethnicities are grouped into one of the following categories: (i) gathering contributes most; (ii) fishing contributes most; (iii) hunting contributes most; (iv) pastoralism contributes most; ( $v$ ) casual agriculture contributes most; (vi) extensive agriculture contributes most; (vii) intensive agriculture contributes most; (viii) two or more sources equally contribute; (ix) agriculture contributes most (type unknown). Our constructed indicator variable captures societies belonging to categories $(v)$, (vi), (vii) or (ix).

Dependence on agriculture/gathering/hunting/fishing/husbandry: we measure the level of dependence from these five production activities using variables v1, v2, v3, v4 and v5 of Murdock's Atlas, which report the share of subsistence obtained from each activity into 9 broad bands. Our measures of dependence on these activities are generated using the middle point of these intervals.

Female participation in agriculture/gathering/hunting/fishing/husbandry: the measure uses variables v50, v51, v52, v53 and v54 from the Ethnographic Atlas. Ethnicities are grouped into one of the following categories measuring female participation in each of the activities of interest: (i) males only; (ii) 
males appreciably more; (iii) equal participation ${ }^{33}$; (iv) females appreciably more; $(v)$ females only ${ }^{34}$. We construct an indicator variable that takes value 1 if there was equal gender participation or if women contributed more than men or if women were the only participants to the considered production activity.

Endogamy: it is constructed from variable v15 of the Ethnographic Atlas.

Stem family: it is constructed from variable v8 of the Ethnographic Atlas, to identify ethnic groups historically characterized by stem families. The other categories in the original variable include: independent nuclear family (both monogamous and occasional polygyny), independent polyandrous families, polygynous (distinguishing between unusual co-wives pattern and usual co-wives pattern), and large extended family.

Polygyny: the measure uses variable v9 from the Ethnographic Atlas, which classifies ethnicities into the following categories based on marital composition: (i) independent nuclear (monogamous); (ii) occasional polygyny; (iii) preferentially sororal (cowives in same dwellings); (iv) preferentially sororal (cowives in separate dwellings); $(v)$ non-sororal (cowives in separate dwellings); (vi) non-sororal (cowives in same dwellings); and (vii) independent polyandrous families. Our constructed indicator variable captures societies belonging to categories (ii), (iii), (iv), (v) or (vi).

Virilocality: it is constructed from variable v12 of the Ethnographic Atlas. Ethnicities are grouped into the following categories based on postmarital residence rules: (i) avunculal; (ii) ambilocal; (iii) optionally uxorilocal or avunculocal; (iv)optionally patrilocal or avunculocal; (v) matrilocal; (vi) neolocal; (vii) no common residence; (viii) patrilocal; (ix) uxorilocal; and $(x)$ virilocal. We create an indicator for ethnic groups that are patrilocal or virilocal.

Nomadic/sedentary/isolated/compact settlements: this measure comes from variale v30 of Murdock's Atlas. Ethnicities are grouped into the following

\footnotetext{
${ }^{33}$ The original classification in Murdock's Atlas makes a distinction between "differentiated but equal participation" and "equal participation, no marked differentiation". Since this distinction is not relevant for our purpose, we decide to combine these two categories.

${ }^{34}$ If the activity is present but sex participation is not specified or if the activity is absent, then there is no measure of female participation.
} 
categories based on settlement patterns: (i) nomadic or fully migratory; (ii) seminomadic; (iii) semisedentary; (iv) compact but impermanent settlements; ( $v$ ) neighborhood of dispersed family homesteads; (vi) separeted hamlets forming a single community; (vii) compact and permanent settlements; and (viii) complex settlements. Starting from this classification, we create a dummy 'Nomadic' equal to one for societies belonging to categories (i) or (ii), a dummy 'Isolated', equal to one for societies beloging to category (v), a dummy 'Compact', which refers to those ethnic groups belonging to categories (iv) or (vii), and a dummy 'Sedentary', including societies belonging to categories (iii), (v), (vi), (vii) or (viii).

\section{A3.2 Contemporary controls}

We use a set of individual covariates as contemporary controls in all our regressions. Most of them are straightforward, like age etc. The wealth index is a continuous variable, calculated by the DHS using data on a household's ownership of selected assets, materials used for housing construction and types of water access and sanitation facilities. All these variables come from the DHS. 